\title{
Alkali metal halogenides coordination compounds with hexamethylenetetramine
}

\author{
Rafal Kruszynski • Tomasz Sieranski • \\ Agnieszka Bilinska $\cdot$ Teresa Bernat • \\ Ewelina Czubacka
}

Received: 22 December 2011/ Accepted: 24 January 2012/Published online: 26 February 2012

(C) The Author(s) 2012. This article is published with open access at Springerlink.com

\begin{abstract}
Six coordination compounds: $\left[\mathrm{Li}\left(\mathrm{H}_{2} \mathrm{O}\right)_{4}\right]^{+}$. hmta $\cdot \mathrm{Cl}^{-},\left[\mathrm{Li}\left(\mathrm{H}_{2} \mathrm{O}\right)_{4}\right]^{+} \cdot \mathrm{hmta} \cdot \mathrm{I}^{-},\left[\mathrm{Na}\left(\mathrm{H}_{2} \mathrm{O}\right)_{4}(\mathrm{hmta})\right]_{2}^{2+} \cdot 2 \mathrm{H}_{2} \mathrm{O}$. $2 \mathrm{Br}^{-}, \quad\left[\mathrm{Na}\left(\mathrm{H}_{2} \mathrm{O}\right)_{4}(\mathrm{hmta})\right]_{2}^{2+} \cdot 2 \mathrm{H}_{2} \mathrm{O} \cdot 2 \mathrm{I}^{-}, \quad\left[\mathrm{K}\left(\mathrm{H}_{2} \mathrm{O}\right)(\mathrm{hmta})\right]_{n}$ and $\left[\mathrm{Rb}\left(\mathrm{H}_{2} \mathrm{O}\right)(\mathrm{hmta}) \mathrm{I}\right]_{n}$, have been synthesized and characterised by IR spectroscopy, thermogravimetry coupled with differential thermal analysis, elemental analysis and X-ray crystallography. Both the sodium compounds are isostructural in a solid state, an isostructurality is also observed between compounds containing potassium and rubidium iodides. The sodium compounds exist as dimers (dinuclear core of the complex ion is created by two sodium cations and two water molecules). The molecules of potassium and rubidium compounds are assembled to the two dimensional hybrid nets. The each potentially multifunctional ligand (the hmta) exists in the outer coordination sphere in lithium compounds, acts in a monodentate mode in sodium compounds and in bidentate-bridging modes in potassium and rubidium compounds. The lithium ions are four coordinated, and the sodium, potassium and rubidium ions are six coordinated. Thermal analyses show that the investigated compounds decompose gradually with the formation of alkali metal halides which, during the further heating, are totally removed or they undergo partial decomposition to oxides.
\end{abstract}

Keywords Alkali metal - Crystal structure · Hexamethylenetetramine · IR spectroscopy · Thermal decomposition

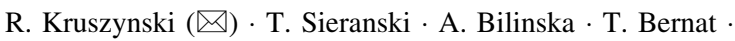
E. Czubacka

Institute of General and Ecological Chemistry, Technical University of Lodz, Zeromskiego 116, 90-924 Lodz, Poland e-mail: rafal.kruszynski@p.lodz.pl

\section{Introduction}

The alkali metal ions play important roles in biological systems, for example they incorporate into important biological molecules such as enzymes [1] proteins and peptides [2-4], nucleotides [5] and membrane lipids [6]. The coordination chemistry of alkali metal cations and their interactions with ligands have been widely studied in the past years [7-10] including the chemistry of molecular clusters [11, 12] or macrocyclic compounds [13-15]. Many of the obtained complex compounds have potential applications in biological, inorganic, and synthetic chemistry $[16,17]$ and in biotechnology [18]. The coordination chemistry of cations such as $\mathrm{Li}^{+}, \mathrm{Na}^{+}$, and $\mathrm{K}^{+}$is of the utmost importance because of their significant role in different biological processes $[19,20]$ especially in the cell biology [21] and natural fluids biochemistry [22, 23]. For example potassium and sodium, together with proteins switching ion channels, are responsible for maintenance of the ionic equilibrium and these cations availability in intercellular fluids are responsible for electrochemical gradients across cell membranes and in consequence for transmitting nerve impulses and regulation of cell functions [21]. The research of compounds containing these cations, their ionic antagonists (like other alkaline metals) with anions existing in body fluids is thus of great importance, as they affect the sodium-potassium pump. In addition, recently, an increasing interest is put on construction of dinuclear, multinuclear and polymeric coordination compounds [24-27] created by self-assembly [28] of the components [29-32].

The present study is a continuation of investigations of the alkali metal salts properties with commercially used antiseptic drug [33], the hexamethylenetetramine which is a clathrate non-chelating neutral $\mathrm{N}$-donor ligand. The hmta 


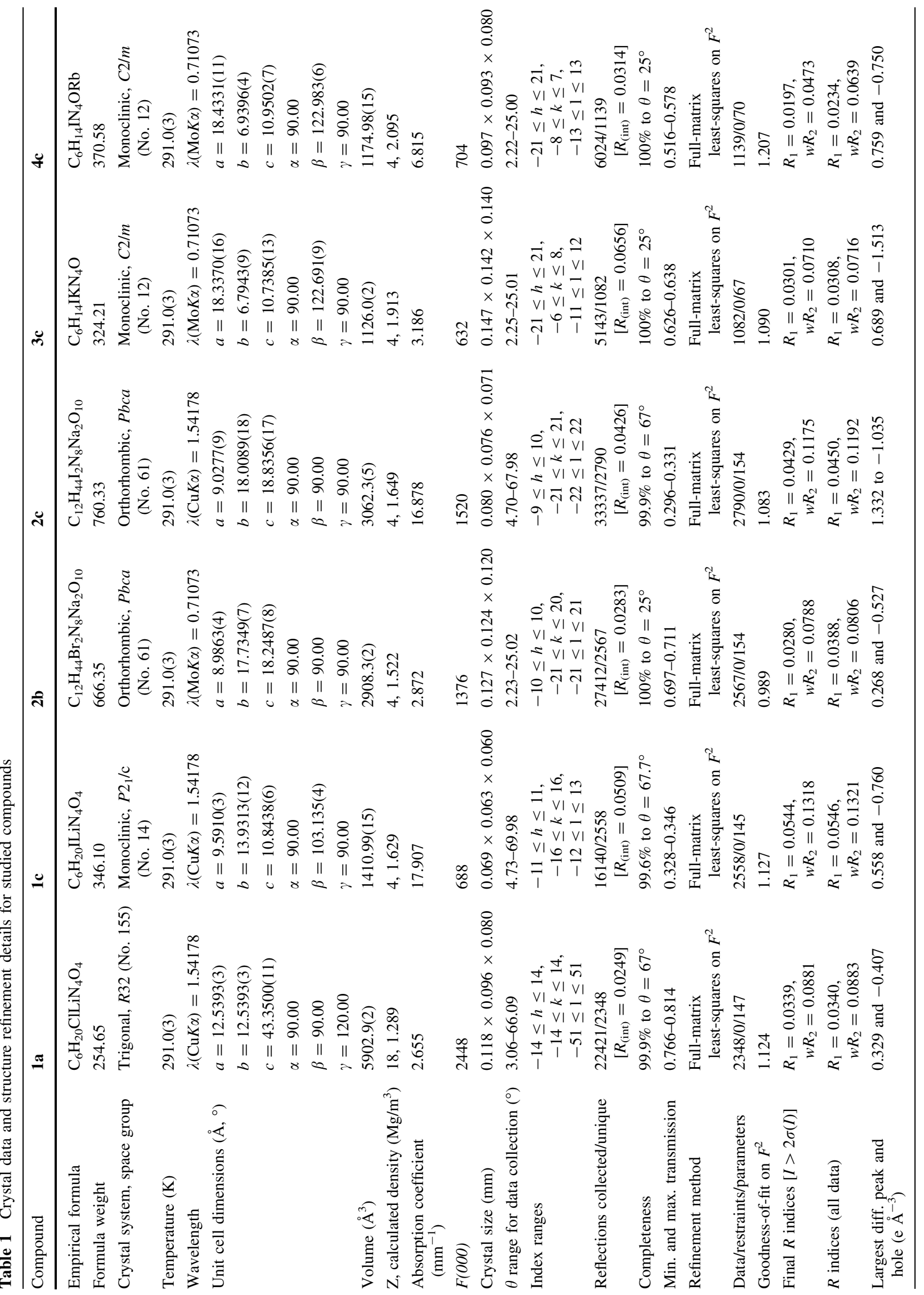


in aqueous media can act as a multifunctional ligand (up to tetradentate mode) and as a multidentate acceptor of hydrogen bonds able to create versatile intramolecular networks [34, 35] and to create ligand-metal-ligand type supramolecular architectures [36-39]. The main goal of the present study was evaluation of the structural behaviour of the alkali metal halides in the presence of hmta in a solid state, and assessing the possibility of multinuclear species formation.

\section{Experimental}

Materials and synthesis

All chemicals (analytical grade) were obtained from POCh S.A. and used without further purification. The complex compounds $\left[\mathrm{Li}\left(\mathrm{H}_{2} \mathrm{O}\right)_{4}\right]^{+} \cdot \mathrm{hmta} \cdot \mathrm{Cl}^{-}(\mathrm{la}),\left[\mathrm{Li}\left(\mathrm{H}_{2} \mathrm{O}\right)_{4}\right]^{+} \cdot \mathrm{hmta}$ $\cdot \mathrm{I}^{-}(1 \mathrm{c}),\left[\mathrm{Na}\left(\mathrm{H}_{2} \mathrm{O}\right)_{4}(\mathrm{hmta})\right]_{2}^{2+} \cdot 2 \mathrm{H}_{2} \mathrm{O} \cdot 2 \mathrm{Br}^{-}(2 \mathrm{~b}),\left[\mathrm{Na}\left(\mathrm{H}_{2} \mathrm{O}\right)_{4}\right.$ $(\mathrm{hmta})]_{2}^{2+} \cdot 2 \mathrm{H}_{2} \mathrm{O} \cdot 2 \mathrm{I}^{-}(2 \mathrm{c}),\left[\mathrm{K}\left(\mathrm{H}_{2} \mathrm{O}\right)(\mathrm{hmta}) \mathrm{I}\right]_{n}(3 \mathrm{c})$ and $[\mathrm{Rb}$ $\left.\left(\mathrm{H}_{2} \mathrm{O}\right)(\mathrm{hmta}) \mathrm{I}\right]_{n}(4 \mathrm{c})$ were obtained in a direct reaction between the salt and the ligand. The lithium chloride, lithium iodide, sodium bromide, sodium iodide, potassium iodide and rubidium iodide $(0.0420,0.1338,0.1030,0.1499,0.1660$, and $0.2120 \mathrm{~g}$, respectively, for $1 \mathrm{a}, 1 \mathrm{c}, 2 \mathrm{~b}, 2 \mathrm{c}, 3 \mathrm{c}$, and $4 \mathrm{c}$ ) were dissolved in $5 \mathrm{~cm}^{3}$, for $1 \mathrm{c}, 3$ and 4 , in $3 \mathrm{~cm}^{3}$ for $2 \mathrm{~b}$ and $2 \mathrm{c}$, and in $4 \mathrm{~cm}^{3}$ for 1 , of water and then they were mixed with aqueous solutions of hexamethylenetetramine (molar ratio 1:1). The mixtures were stirred vigorously for $0.5 \mathrm{~h}$, for $\mathbf{2 b}$ and $\mathbf{3}$, and $3 \mathrm{~h}$, for 1a, 1c, 2c, and $\mathbf{4 c}$, on a magnetic stirrer, placed in a refrigerator and left to crystallize at temperature of $5{ }^{\circ} \mathrm{C}$ ). After 6 (2b) and 12 weeks (1a, 1c, 2c, 3c and 4c) the crystals grown. The products were filtered off and dried in air. The mixing of hmta with following salts: $\mathrm{MF}(\mathrm{M}=\mathrm{Li}, \mathrm{Na}, \mathrm{K}, \mathrm{Rb}$ or $\mathrm{Cs}$ ), $\mathrm{NaCl}, \mathrm{KCl}, \mathrm{KBr}, \mathrm{RbCl}, \mathrm{RbBr}$ or $\mathrm{CsX}(\mathrm{X}=\mathrm{F}, \mathrm{Cl}, \mathrm{Br}, \mathrm{I})$ at different proportions (2:1, 1:1 and 1:2) always leads to separate crystallisation (after 7-26 weeks) of pure hmta and pure inorganic salt (the compositions of these samples were confirmed by XRPD, identically as described below for thermal decomposition products). The compound $\left[\mathrm{Li}\left(\mathrm{H}_{2} \mathrm{O}\right)_{4}\right]^{+}$. hmta $\cdot \mathrm{Br}^{-}$(1) $)$is formed in a solid state, however it always crystallises as fine crystalline powder changing to the amorphous powder outside the solution, and all attempts to obtain single crystals failed.

\section{X-ray crystallography}

Colourless rectangular prism shape crystals were mounted in turn on a KM-4-CCD automatic diffractometer equipped with CCD detector, and used for data collection. X-ray intensity data were collected with graphite monochromated $\operatorname{Mo} K_{\alpha}$ or $\mathrm{Cu} K \alpha$ radiation (Table 1) at temperature 291.0(3) K, with $\omega$ scan mode. The 11-36 s exposures times were used and reflections inside Ewald sphere were collected up to $\theta=25^{\circ}$ and $\theta=67^{\circ}$, respectively, for $\operatorname{Mo} K_{\alpha}$ and $\mathrm{Cu} K \alpha$ radiation. The unit cells parameters were determined from least-squares refinement of the $4615,784,3615,3408,836$ and 4072 strongest reflections, respectively, for $\mathbf{1 a}, \mathbf{1 c}, \mathbf{2 b}, \mathbf{2 c}, \mathbf{3 c}$ and 4c. Details concerning crystal data and refinement are given in Table 1. Examination of reflections on two reference frames monitored after each 20 frames measured showed no loss of the intensity during measurements. Lorentz, polarization, and numerical absorption [40] corrections were applied. The structures were solved by direct methods. All the non-hydrogen atoms were refined anisotropically using fullmatrix, least-squares technique on $F^{2}$. All the hydrogen atoms were found from difference Fourier synthesis after four cycles of anisotropic refinement, and refined as "riding" on the adjacent atom with individual isotropic displacement factor equal 1.2 times the value of equivalent displacement factor of the patent carbon atoms and 1.5 times for patent oxygen atoms. The carbon bonded hydrogen atom positions were idealised after each cycle of refinement. The SHELXS97, SHELXL97 and SHELXTL [41] software was used for all the calculations. Atomic scattering factors were those incorporated in the computer programs. Selected interatomic bond distances and angles are listed in Table 2, and geometrical parameters of intermolecular interactions are listed in Table 3 .

\section{Physical measurements}

IR spectra were recorded on a Jasco FT/IR 6200 spectrophotometer in the spectral range $4,000-400 \mathrm{~cm}^{-1}$ with the samples in the form of $\mathrm{KBr}$ pellets. The thermal analyses were carried out in a TG-DTA-SETSYS-16/18 thermoanalyser coupled with ThermoStar (Balzers) mass spectrometer. The samples were heated in corundum crucibles up to $1200{ }^{\circ} \mathrm{C}$ at a heating rate of $2{ }^{\circ} \mathrm{C} / \mathrm{min}$ in air atmosphere. The processes temperature ranges were determined by means of thermoanalyser Data Processing Module [42]. The solid products of the thermal decomposition were determined from derivatographic curves and on the basis of IR spectra and elemental analyses of the sinters. The final and some transition products of the decomposition were confirmed by X-ray powder diffraction (XRPD) using the powder diffraction file [43]. Elemental analyses were carried out using a Vario EL III CHNOS Elemental Analyzer (C, H, N, O). The alkali metal contents were determined by flame spectrophotometry in mineralised samples. The content of the halogenide ions were determined by potentiometric titrations of mineralised samples with $\mathrm{AgNO}_{3}$ used as a titrant. Elemental analyses for studied compounds [Calculated/Found (\%)] (1a): C 28.30/28.22, H 7.92/7.99, O 25.13/25.00, N 22.00/21.97, Li 2.73/2.74, Cl 13.92/ 14.06; (1b): C 24.09/23.95, H 6.69/6.98, O 21.42/22.16, N 


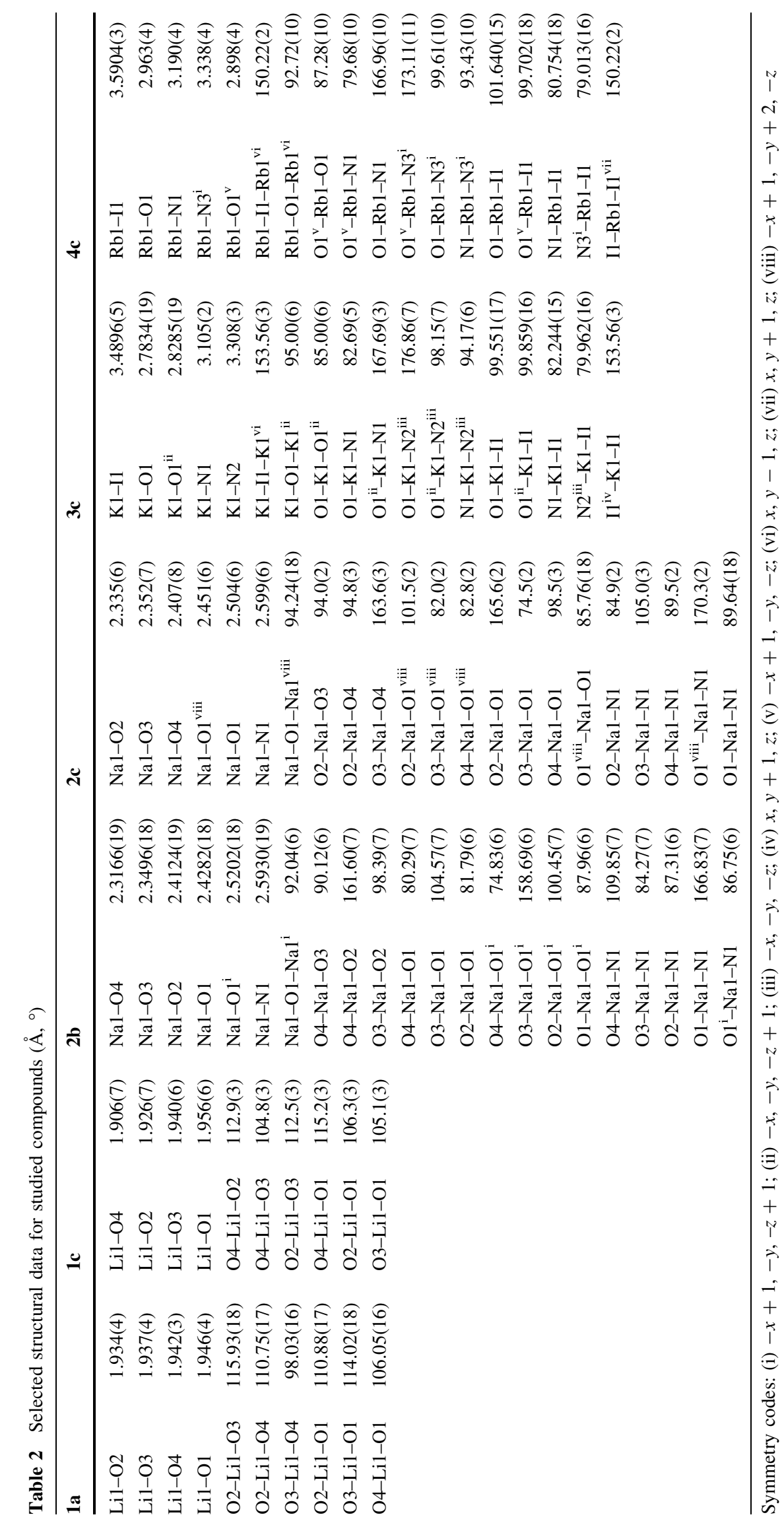


Table 3 Hydrogen bonds in studied compounds $\left(\AA{ }^{\circ}{ }^{\circ}\right)$

\begin{tabular}{|c|c|c|c|c|}
\hline & D-H & $\mathrm{H} \cdots \mathrm{A}$ & $\mathrm{D} \cdots \mathrm{A}$ & $\mathrm{D}-\mathrm{H} \cdots \mathrm{A}$ \\
\hline \multicolumn{5}{|l|}{$1 \mathbf{a}$} \\
\hline $\mathrm{O} 1-\mathrm{H} 1 \mathrm{O} \cdots \mathrm{Cl} 1^{\mathrm{i}}$ & 0.95 & 2.20 & $3.1493(14)$ & 175.0 \\
\hline $\mathrm{O} 1-\mathrm{H} 1 \mathrm{P} \cdots \mathrm{N} 12^{\mathrm{ii}}$ & 0.87 & 2.07 & $2.907(2)$ & 159.5 \\
\hline $\mathrm{O} 2-\mathrm{H} 2 \mathrm{O} \cdots \mathrm{N} 2^{\mathrm{iii}}$ & 0.94 & 1.95 & $2.883(2)$ & 175.2 \\
\hline $\mathrm{O} 2-\mathrm{H} 2 \mathrm{P} \cdots \mathrm{Cl} 3$ & 0.97 & 2.21 & $3.1777(16)$ & 174.0 \\
\hline $\mathrm{O} 3-\mathrm{H} 3 \mathrm{O} \cdots \mathrm{N} 1^{\mathrm{iv}}$ & 0.90 & 1.91 & $2.783(2)$ & 163.0 \\
\hline O3-H3P $\cdots \mathrm{Cl} 2$ & 0.93 & 2.33 & $3.2346(16)$ & 167.1 \\
\hline $\mathrm{O} 4-\mathrm{H} 4 \mathrm{O} \cdots \mathrm{N} 11$ & 0.90 & 1.92 & $2.801(2)$ & 165.8 \\
\hline $\mathrm{O} 4-\mathrm{H} 4 \mathrm{P} \cdots \mathrm{Cl} 2$ & 0.94 & 2.33 & $3.2000(15)$ & 154.8 \\
\hline \multicolumn{5}{|l|}{ 1c } \\
\hline $\mathrm{O} 1-\mathrm{H} 1 \mathrm{O} \cdots \mathrm{N} 2^{\mathrm{v}}$ & 0.87 & 1.95 & $2.799(4)$ & 166.9 \\
\hline $\mathrm{O} 1-\mathrm{H} 1 \mathrm{P} \cdots \mathrm{I} 1^{\mathrm{vi}}$ & 0.91 & 2.69 & $3.590(4)$ & 172.1 \\
\hline $\mathrm{O} 2-\mathrm{H} 2 \mathrm{O} \cdots \mathrm{N} 3$ & 0.92 & 1.98 & $2.886(4)$ & 167.2 \\
\hline $\mathrm{O} 2-\mathrm{H} 2 \mathrm{P} \cdots \mathrm{N} 4^{\mathrm{vii}}$ & 0.96 & 1.91 & $2.861(4)$ & 167.5 \\
\hline $\mathrm{O} 3-\mathrm{H} 3 \mathrm{O} \cdots \mathrm{I} 1^{\text {viii }}$ & 0.97 & 2.60 & $3.563(3)$ & 172.1 \\
\hline 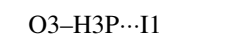 & 0.95 & 2.64 & $3.555(3)$ & 163.9 \\
\hline $\mathrm{O} 4-\mathrm{H} 4 \mathrm{O} \cdots \mathrm{O} 1^{\mathrm{vii}}$ & 0.83 & 2.12 & $2.936(4)$ & 169.3 \\
\hline $\mathrm{O} 4-\mathrm{H} 4 \mathrm{P} \cdots \mathrm{N} 1^{\mathrm{ix}}$ & 0.94 & 1.89 & $2.820(4)$ & 170.3 \\
\hline \multicolumn{5}{|l|}{$2 b$} \\
\hline $\mathrm{O} 1-\mathrm{H} 1 \mathrm{O} \cdots \mathrm{N} 4^{\mathrm{v}}$ & 0.90 & 1.95 & $2.846(2)$ & 171.9 \\
\hline $\mathrm{O} 1-\mathrm{H} 1 \mathrm{P} \cdots \mathrm{Br} 1^{\mathrm{x}}$ & 0.87 & 2.90 & $3.7099(16)$ & 156.5 \\
\hline $\mathrm{O} 2-\mathrm{H} 2 \mathrm{O} \cdots \mathrm{O} 11$ & 0.89 & 2.03 & $2.900(3)$ & 166.2 \\
\hline $\mathrm{O} 2-\mathrm{H} 2 \mathrm{P} \cdots \mathrm{O} 11^{\mathrm{xi}}$ & 0.97 & 1.98 & 2.933(3) & 167.9 \\
\hline $\mathrm{O} 3-\mathrm{H} 3 \mathrm{O} \cdots \mathrm{Br} 1^{\mathrm{xii}}$ & 0.90 & 2.53 & $3.4232(16)$ & 174.9 \\
\hline $\mathrm{O} 3-\mathrm{H} 3 \mathrm{P} \cdots \mathrm{N} 2^{\mathrm{xi}}$ & 0.91 & 1.94 & $2.849(2)$ & 174.1 \\
\hline $\mathrm{O} 4-\mathrm{H} 4 \mathrm{O} \cdots \mathrm{O} 2^{\mathrm{x}}$ & 0.92 & 2.07 & 2.974(3) & 166.6 \\
\hline $\mathrm{O} 4-\mathrm{H} 4 \mathrm{P} \cdots \mathrm{N} 3^{\mathrm{xii}}$ & 0.89 & 1.91 & $2.799(2)$ & 175.6 \\
\hline $\mathrm{O} 11-\mathrm{H} 11 \mathrm{O} \cdots \mathrm{Br} 1^{\mathrm{xiii}}$ & 0.92 & 2.42 & $3.2935(19)$ & 158.6 \\
\hline $\mathrm{O} 11-\mathrm{H} 11 \mathrm{P} \cdots \mathrm{Br} 1^{\mathrm{xiv}}$ & 0.94 & 2.38 & $3.2625(19)$ & 156.6 \\
\hline \multicolumn{5}{|l|}{$2 c$} \\
\hline $\mathrm{O} 1-\mathrm{H} 1 \mathrm{O} \cdots \mathrm{N} 2^{\mathrm{xv}}$ & 0.80 & 2.06 & $2.857(7)$ & 168.7 \\
\hline $\mathrm{O} 2-\mathrm{H} 2 \mathrm{O} \cdots \mathrm{N} 4^{\mathrm{xvi}}$ & 0.72 & 2.17 & $2.877(8)$ & 169.5 \\
\hline $\mathrm{O} 2-\mathrm{H} 2 \mathrm{P} \cdots \mathrm{I}^{\mathrm{xvii}}$ & 0.89 & 2.69 & $3.584(6)$ & 179.6 \\
\hline $\mathrm{O} 3-\mathrm{H} 3 \mathrm{O} \cdots \mathrm{O} 4^{\mathrm{xviii}}$ & 0.90 & 2.13 & $3.028(12)$ & 178.2 \\
\hline $\mathrm{O} 3-\mathrm{H} 3 \mathrm{P} \cdots \mathrm{N} 3^{\mathrm{xix}}$ & 0.86 & 1.98 & $2.833(8)$ & 177.7 \\
\hline $\mathrm{O} 4-\mathrm{H} 4 \mathrm{O} \cdots \mathrm{O} 99$ & 0.96 & 2.01 & $2.968(13)$ & 174.4 \\
\hline $\mathrm{O} 4-\mathrm{H} 4 \mathrm{P} \cdots \mathrm{O} 99^{\mathrm{xvi}}$ & 0.99 & 2.00 & $2.992(14)$ & 175.7 \\
\hline 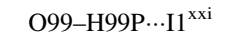 & 0.86 & 2.60 & $3.456(9)$ & 177.3 \\
\hline O99-H99O $\cdots \mathrm{I}^{\mathrm{xi}}$ & 0.90 & 2.58 & $3.419(9)$ & 155.8 \\
\hline $\mathrm{C} 4-\mathrm{H} 4 \mathrm{~B} \cdots \mathrm{O} 99$ & 0.97 & 2.58 & $3.543(12)$ & 171.3 \\
\hline \multicolumn{5}{|l|}{$3 c$} \\
\hline $\mathrm{O} 1-\mathrm{H} 1 \mathrm{O} \cdots \mathrm{N} 3^{\mathrm{xxi}}$ & 0.92 & 1.97 & $2.876(2)$ & 169 \\
\hline \multicolumn{5}{|l|}{$4 \mathrm{c}$} \\
\hline $\mathrm{O} 1-\mathrm{H} 1 \mathrm{O} \cdots \mathrm{N} 2^{\mathrm{xxii}}$ & 0.87 & 1.99 & $2.863(4)$ & 173.4 \\
\hline
\end{tabular}

Symmetry codes: (i) $x-1, y, z$; (ii) $x-y-1 / 3,-y+1 / 3,-z+1 / 3$; (iii) $x,-x+y,-z$; (iv) $-x+y,-x+1,+z$; (v) $x+1, y, z$; (vi) $-x+2, y-0.5$, $-z+0.5$; (vii) $x,-y+0.5, z-0.5$; (viii) $-x+2,-y+1,-z$; (ix) $-x+1$, $-y,-z$; (x) $-x+1,-y,-z+1$; (xi) $x+0.5, y,-z+0.5$; (xii) $x+0.5$, $-y+0.5,-z+1 ;$ (xiii) $-x,-y,-z+1$; (xiv) $-x+0.5,-y, z-0.5$; (xv) $-x+2,-y+2,-z$; (xvi) $x-0.5, y,-z+0.5$; (xvii) $-x+0.5, y+0.5, z$; (xviii) $-x+1,-y+2,-z$; (xix) $x-0.5,-y+2.5,-z$; (xx) $x+1, y, z$; (xxi) $-x+0.5,-y+0.5,-z+1 ;(x x i i) x+0.5, y-0.5, z$
18.74/18.50, Li 6.69/6.23, Br 26.74/26.22; (1c): C 20.82/ 20.76, H 5.82/5.93, O 18.49/18.54, N 16.19/16.11, Li 2.01/ 2.24, I 36.66/36.98; (2b): C 24.61/24.69, H 6.60/6.51, N 16.81/16.68, Na 6.90/6.95, Br 23.98/23.54; (2c): C 18.94/ 19.01, H 5.79/5.67, N 14.73/14.70, Na 6.04/5.97, I 33.38/ 33.30; (3c): C 22.21/22.18, H 4.32/4.39, N 17.27/17.22, K 12.06/11.87, I 39.14/39.30; (4c): C 19.42/19.32, H 3.78/ 3.85, N 15.11/15.00, Rb 23.06/23.62, I 34.24/34.01.

\section{Results and discussion}

The perspective views of the studied compounds are shown in Figs. 1, 2, 3, 4, 5, and 6. The compounds $\mathbf{2 b}$ and $\mathbf{2 c}$ are isostructural in a solid state and the isostructurality is also observed for compounds $\mathbf{3 c}$ and $\mathbf{4 c}$. The four carbon atoms of two hmta molecules of compound 1 lie on the two-fold rotation axis (special position $d$ of the $R 32$ space group at

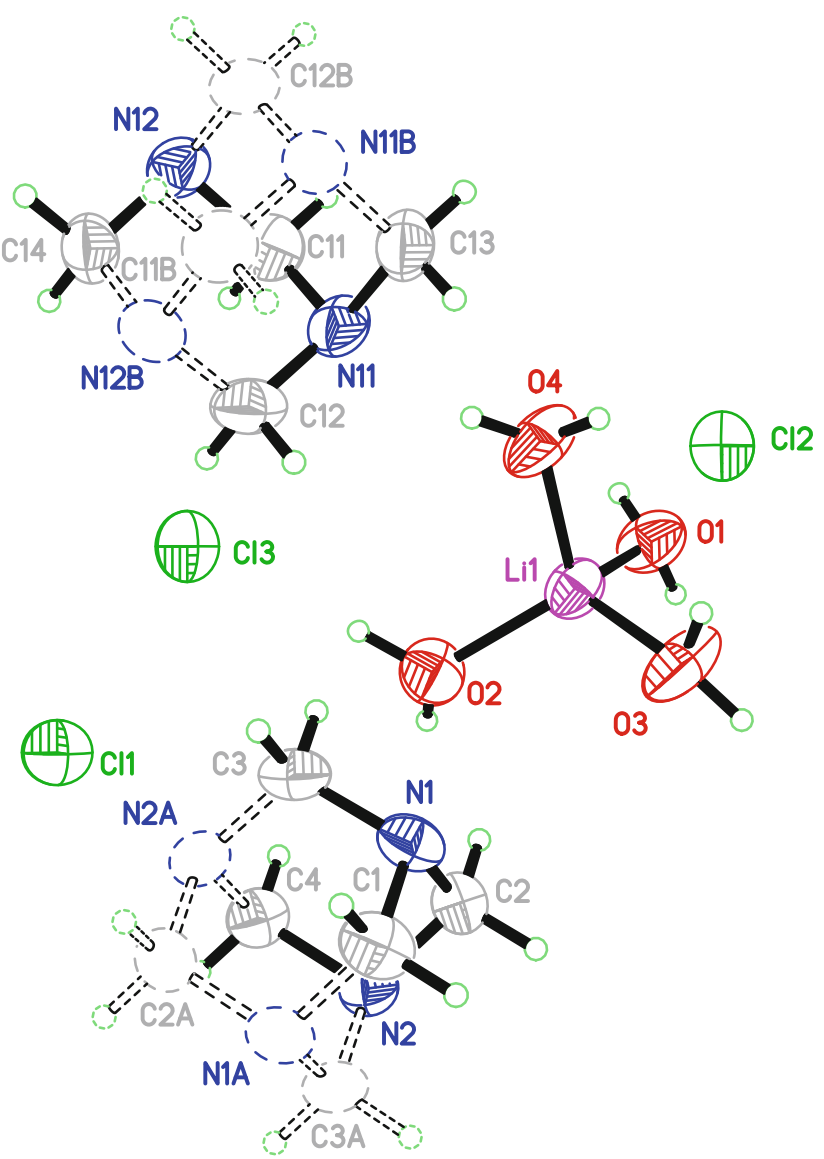

Fig. 1 The molecular conformation of compound 1a with atom numbering, plotted with $50 \%$ probability of displacement ellipsoids. The hydrogen atoms are drawn as spheres of arbitrary radii. The symmetry generated atoms (indicated by dashed lines) are obtained by $y, x,-z$ and $-x+2 / 3,-x+y+1 / 3,-z+1 / 3-x,-y+1$, $-z+1$ symmetry transformation, respectively for atoms with "A" and " $\mathrm{B}$ " suffix letters 


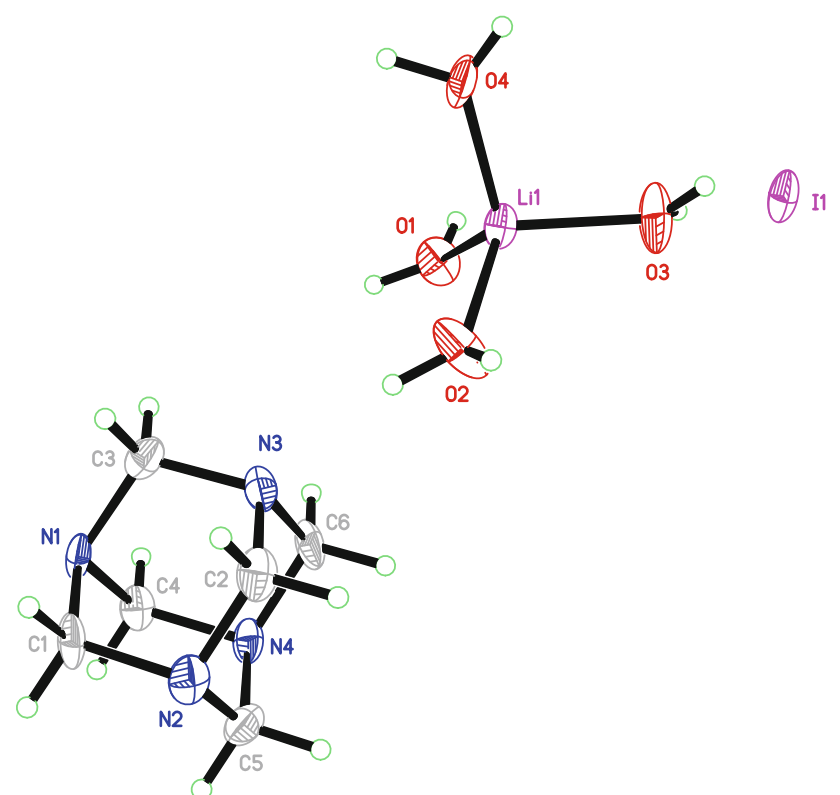

Fig. 2 The molecular conformation of compound 1c with atom numbering, plotted with $50 \%$ probability of displacement ellipsoids. The hydrogen atoms are drawn as spheres of arbitrary radii

$-x,-x, 0$, for $\mathrm{C} 1$ and $\mathrm{C} 4$ atoms and at $0, x, 0$, for $\mathrm{C} 11$ and $\mathrm{C} 41$ atoms) and three chloride ions occupy special positions $c$ with site symmetry 3 (three-fold rotation axis) at 0 , $0, z$. Thus, the asymmetric unit of 1a contains one $\left[\mathrm{Li}\left(\mathrm{H}_{2} \mathrm{O}\right)_{4}\right]^{+}$complex cation, a half of two hmta molecules and one-third of three chloride anions. All atoms of compound 1c lie in general positions and thus, the asymmetric unit is composed from one $\left[\mathrm{Li}\left(\mathrm{H}_{2} \mathrm{O}\right)_{4}\right]^{+}$complex cation, one hmta molecule and one iodide anion. All atoms of compound $\mathbf{2 b}$ and $\mathbf{2 c}$ also lie in general positions, but the complex molecules have the internal inversion centres at 0.5, 0, 0 (special position $b$ of the Pbca space group) and thus each of them occupies the two asymmetric units. In compounds $\mathbf{3 c}$ and $\mathbf{4 c}$ the iodide anions, metal cations, water molecules, two nitrogen and two carbon atoms of each hmta molecule are located on the mirror plane (special position $j$ of the $C 2 / m$ space group at $x, 0, z$ ), therefore, the asymmetric unit contains half of the $\mathrm{M}_{3}\left(\mathrm{H}_{2} \mathrm{O}\right)(\mathrm{hmta}) \mathrm{I}$ $\left(\mathrm{M}_{3}=\mathrm{K}\right.$ and $\left.\mathrm{Rb}\right)$ moiety. The above mentioned mirror plane expands the asymmetric unit to the two dimensional hybrid compound extending along crystallographic (100) plane (Fig. 7). The metal centres of $\mathbf{3 c}$ and $\mathbf{4 c}$ create the 4-c uninodal sql/Shubnikov tetragonal plane net, described by $\left\{4^{4} .6^{2}\right\}$ Schläfli symbol and [4.4.4.4.6(2)0.6(2)] extended point symbol. Some atoms (especially uncoordinated water molecules oxygen atoms and uncoordinated anions) of presented compounds show minor symptoms of disorder what manifests in slightly prolating displacement ellipsoids. Each lithium cation is four coordinated by the four oxygen atoms of water molecules, each sodium cation is six coordinated by one monodentate hmta molecule, three terminal water molecules and two bridging water molecules (analogically to the sodium thiocyanate coordination compound with hmta [44]), and the potassium and rubidium cations are six coordinated by two bridging bidentate

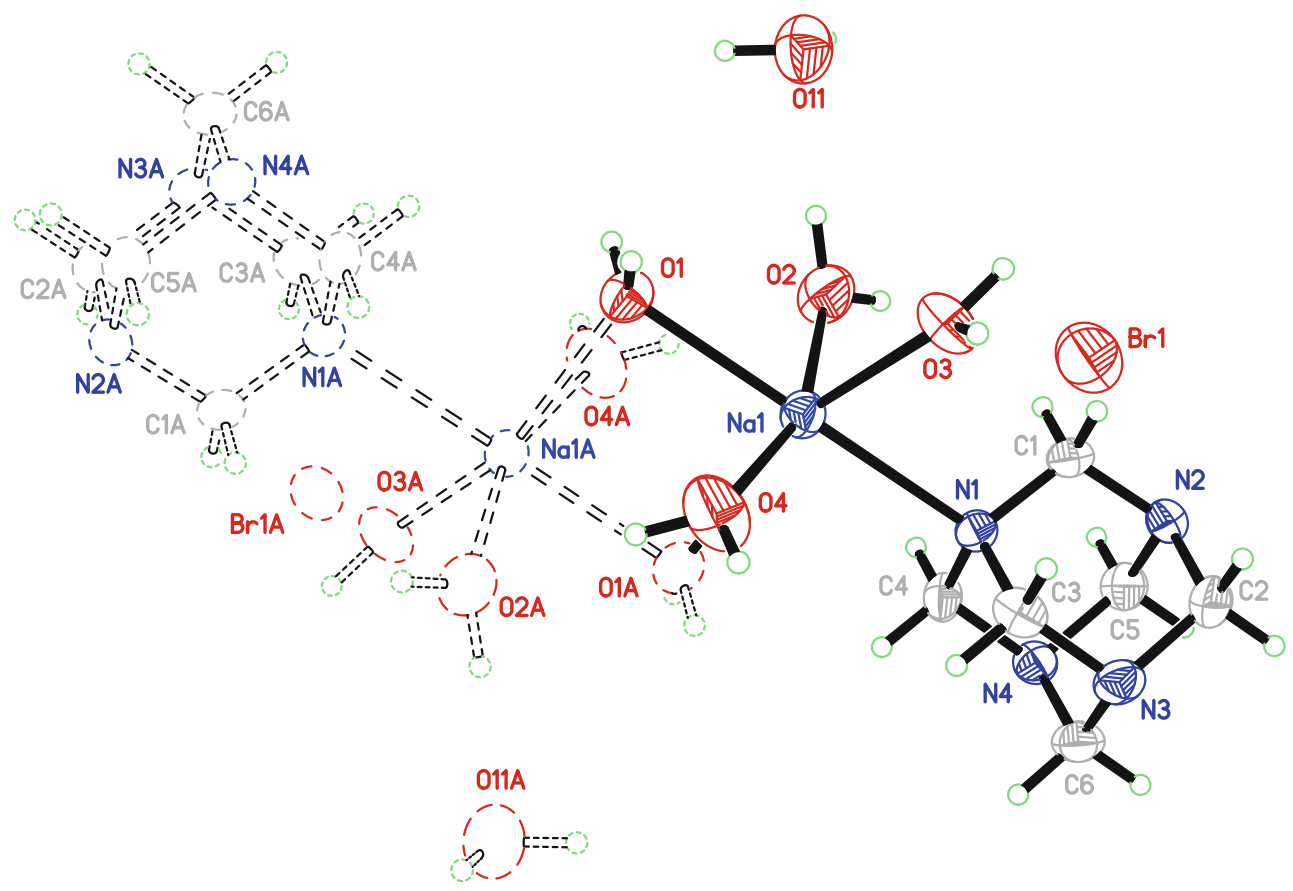

Fig. 3 The molecular conformation of compound $\mathbf{2 b}$ with atom numbering, plotted with $50 \%$ probability of displacement ellipsoids. The hydrogen atoms are drawn as spheres of arbitrary radii. The symmetry generated atoms indicated by dashed lines are obtained by $-x+1,-y,-z+1$ symmetry transformation 


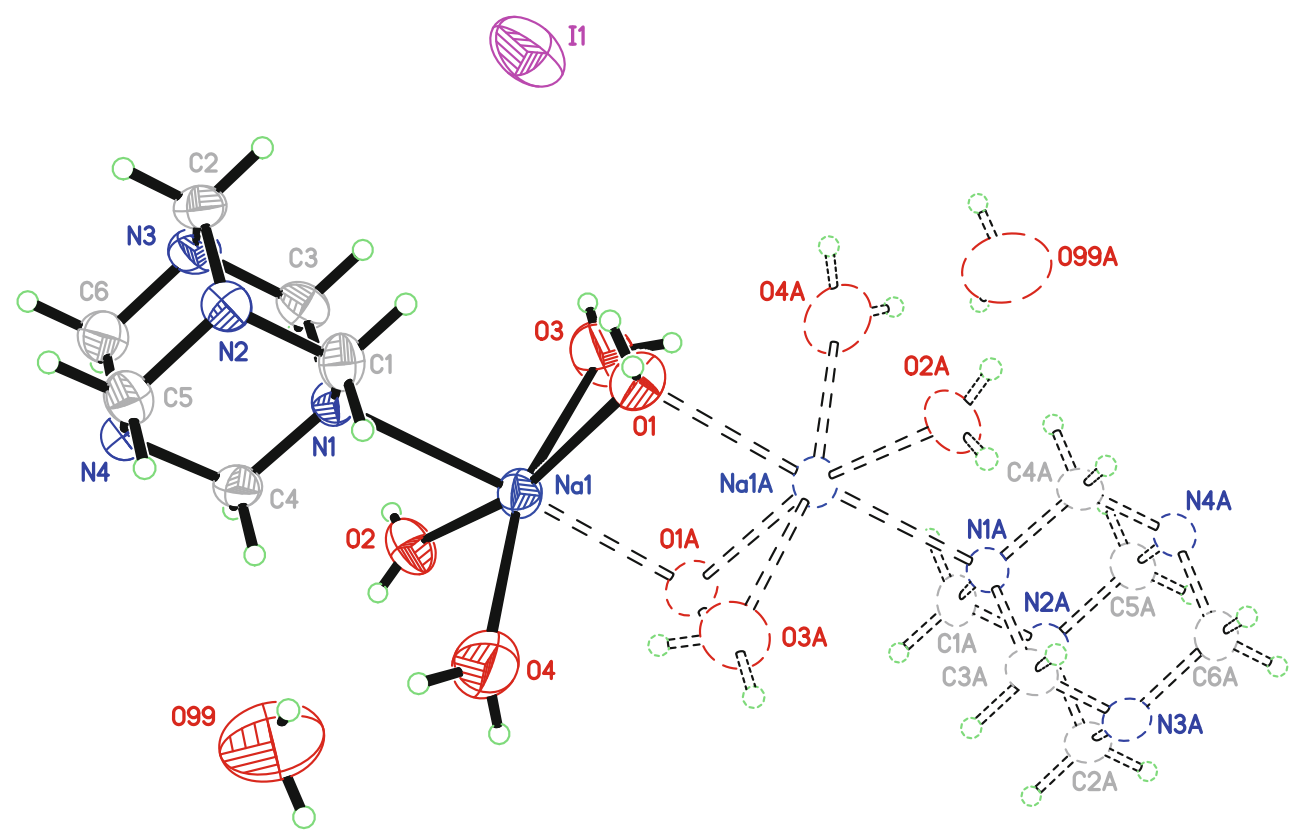

Fig. 4 The molecular conformation of compound 2c with atom numbering, plotted with $50 \%$ probability of displacement ellipsoids. The hydrogen atoms are drawn as spheres of arbitrary radii. The

symmetry generated atoms indicated by dashed lines are obtained by $-x+1,-y+2,-z$ symmetry transformation
Fig. 5 The molecular conformation of compound $\mathbf{3 c}$ with atom numbering, plotted with $50 \%$ probability of displacement ellipsoids. The hydrogen atoms are drawn as spheres of arbitrary radii. The symmetry generated atoms indicated by dashed lines are obtained by symmetry transformations $(\mathrm{C} 2 \mathrm{~A}, \mathrm{C} 3 \mathrm{~A}$, H2AA, H2BA, H3AA, H3BA, IA1: $x,-y, z ; \mathrm{N} 2 \mathrm{~A}:-x, y,-z$; $\mathrm{K} 1 \mathrm{~A}:-x,-y,-z ; \mathrm{K} 1 \mathrm{~B}, \mathrm{O} 1 \mathrm{~A}$ : $-x,-y,-z+1)$

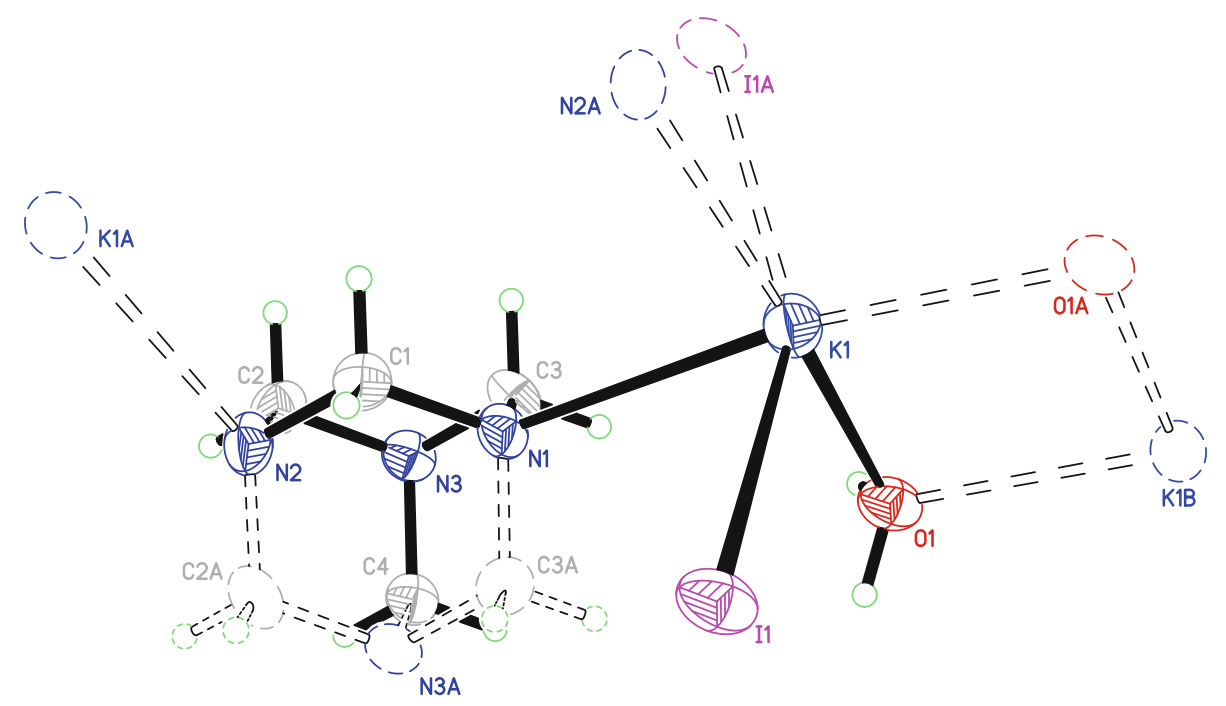

hmta molecules, two bridging iodide ions and two bridging oxygen atoms of water molecules. All bridging water molecules are asymmetrically bonded to the metal ions (Table 2). The coordination polyhedra of the lithium cations can be described as slightly distorted tetrahedra (the sum of the polyhedra internal interbond angles are 655.7 and $656.8^{\circ}$, respectively for $\mathbf{1 a}$ and $\mathbf{1 c}$, what is close to the ideal value of $656.8^{\circ}$ ) and sodium, potassium and rubidium cations as distorted tetragonal bipyramids (Fig. 8, Table 4). In both sodium complex compounds the least deformed is the polyhedron base containing one bridging water molecule, one nitrogen atom and two terminal water molecules, whilst in compounds $\mathbf{3 c}$ and $\mathbf{4 c}$ the polyhedron bases containing two nitrogen and two oxygen atoms are planar by symmetry (Table 4 , Fig. 8 ). The sodium cations are placed close to the polyhedra centres, and potassium and rubidium cations are slightly displaced from such centres (Table 4).

The bond valences were computed as $v_{i j}=\exp \left[\left(R_{i j}-\right.\right.$ $\left.d_{i j}\right) / b$ ] [45, 46], where $R_{i j}$ is the bond-valence parameter (in 
Fig. 6 The molecular conformation of compound $\mathbf{4 c}$ with atom numbering, plotted with $50 \%$ probability of displacement ellipsoids. The hydrogen atoms are drawn as spheres of arbitrary radii. The symmetry generated atoms indicated by dashed lines are obtained by symmetry transformations $(\mathrm{C} 1 \mathrm{~A}, \mathrm{C} 2 \mathrm{~A}$, N2A, H1AA, H1BA, H2AA, H2BA, H1O: $x,-y, z ; \mathrm{N} 3 \mathrm{~A}$, Rb1A: $-x+1,-y,-z+1$; Rb1B, O1A: $-x+1,-y,-z$ )

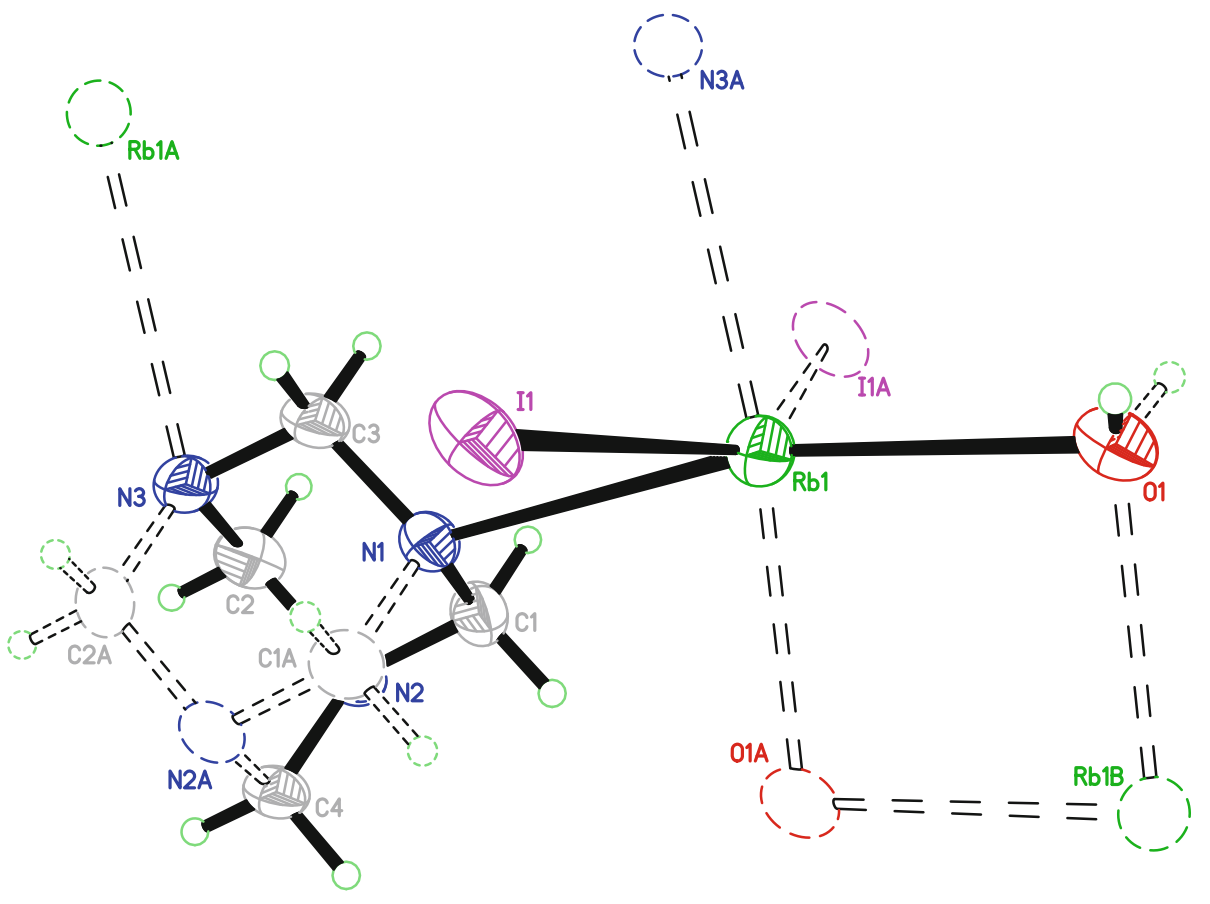

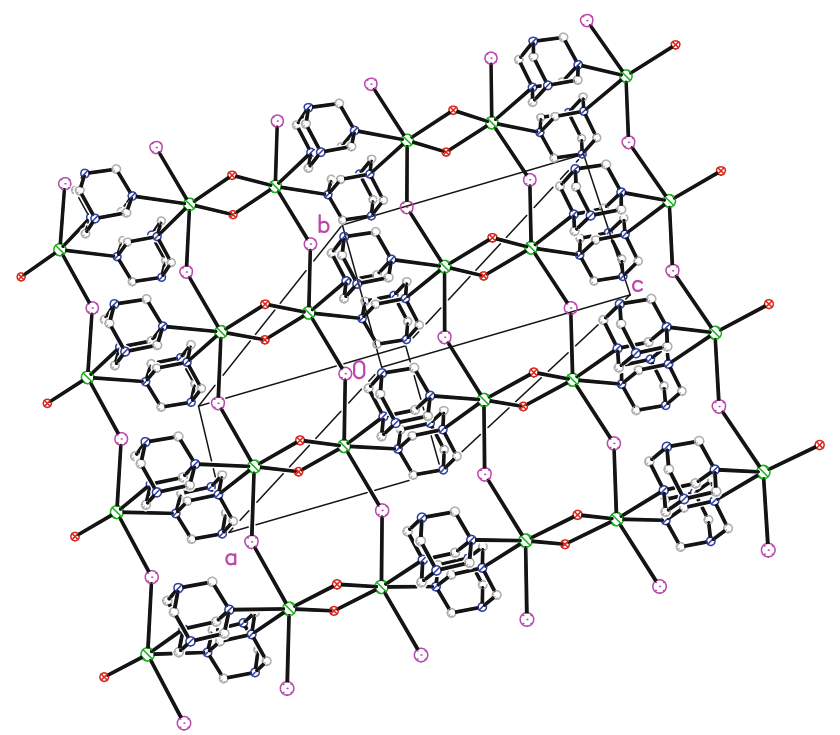

Fig. 7 A part of molecular packing of compounds $3 c$ and $4 c$ showing the two dimensional hybrid net. The hydrogen atoms are omitted for clarity

the formal sense $R_{i j}$ can be considered as a parameter equal to the idealised single-bond length between $i$ and $j$ atoms for given $b$ ) and $b$ was taken as $0.37 \AA$ [47-50]. The $R_{\mathrm{Li}-\mathrm{O}}$, $R_{\mathrm{Na}-\mathrm{O}}, R_{\mathrm{Na}-\mathrm{N}}, R_{\mathrm{K}-\mathrm{N}}, R_{\mathrm{K}-\mathrm{O}}, R_{\mathrm{K}-\mathrm{I}}, R_{\mathrm{Rb}-\mathrm{N}}, R_{\mathrm{Rb}-\mathrm{O}}$, and $R_{\mathrm{Rb}-\mathrm{I}}$ were taken as 1.466, 1.80, 1.93, 2.26, 2.13, 2.28, 2.37, 2.26 and 3.01, respectively [51]. The computed bond valences of the metal ions (Table 5) show that amongst the studied compounds the $\mathrm{Li}-\mathrm{O}$ bonds are the strongest ones (as expected, due to lower coordination number of lithium cation in comparison to other used cations, and, in consequence, sharing valence amongst smaller number of ligands). The all water molecules are bonded to the lithium cation with comparable strengths, whilst in sodium compounds the strongest ones are the two bonds between the metal ions and terminal water molecules, one of $\mathrm{Na}-$ $\mathrm{O}$ (bridging water) bonds is the weakest one and the $\mathrm{Na}-\mathrm{N}$ bonds have strength comparable to the other, above unspecified, $\mathrm{Na}-\mathrm{O}$ bonds. In the potassium and caesium compounds the strongest are $\mathrm{M}_{3}-\mathrm{I}$ bonds, the $\mathrm{M}_{3}-\mathrm{N}$ are the weakest ones, and the $\mathrm{M}_{3}-\mathrm{O}$ bonds have the medium strength in comparison to other coordination bonds. The computed total valences of central atoms are 1.112, 1.137, $1.158,1.140,0.868$ and 0.927 , respectively for compounds 1a, 1c, 2b, 2c, 3c, and 4c. The small overestimating of the formal oxidation states of lithium and sodium originates from relative unimpeded coordination spheres of these metals compounds and underestimation of the formal oxidation states of potassium and rubidium originates from constraints imposed by the relatively rigid hybrid net. The both lithium compounds are assembled by intermolecular hydrogen bonds $[52,53]$ to the three dimensional supramolecular networks, however, in compound 1a each water molecule creates one $\mathrm{O}-\mathrm{H} \cdots \mathrm{N}$ and one $\mathrm{O}-\mathrm{H} \cdots \mathrm{Cl}$ hydrogen bond whilst in compound 1c the three different hydrogen bonds acceptors (N, I, O) are involved into interactions and two water molecules are hydrogen-bonded to the homoatomic acceptors (i.e., one water molecule to two $\mathrm{N}$ atoms and one water molecule to two I atoms, Table 3). Due to isostructurality the hydrogen bonding scheme in $\mathbf{2 b}$ and $\mathbf{2 c}$ is analogous and multiple $\mathrm{O}-\mathrm{H} \cdots \mathrm{N}, \mathrm{O}-\mathrm{H} \cdots \mathrm{O}$ and $\mathrm{O}-\mathrm{H} \cdots \mathrm{X}_{2}$ $\left(\mathrm{X}_{2}=\mathrm{Br}\right.$, I) interactions assemble the molecules to the 

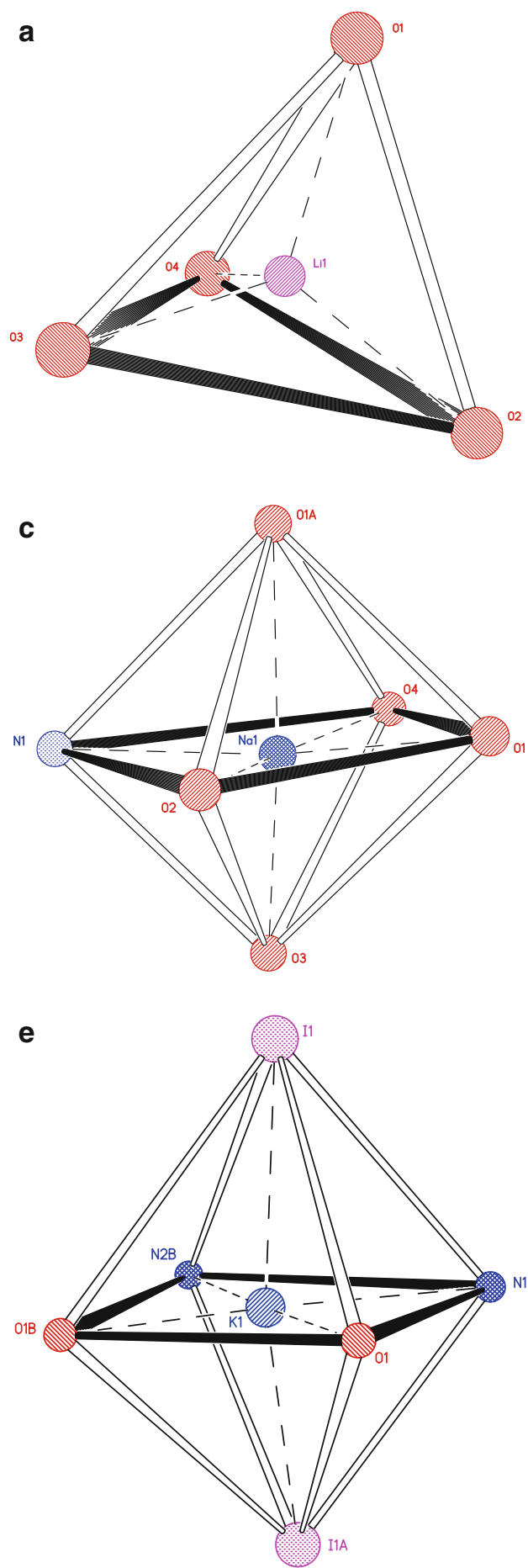
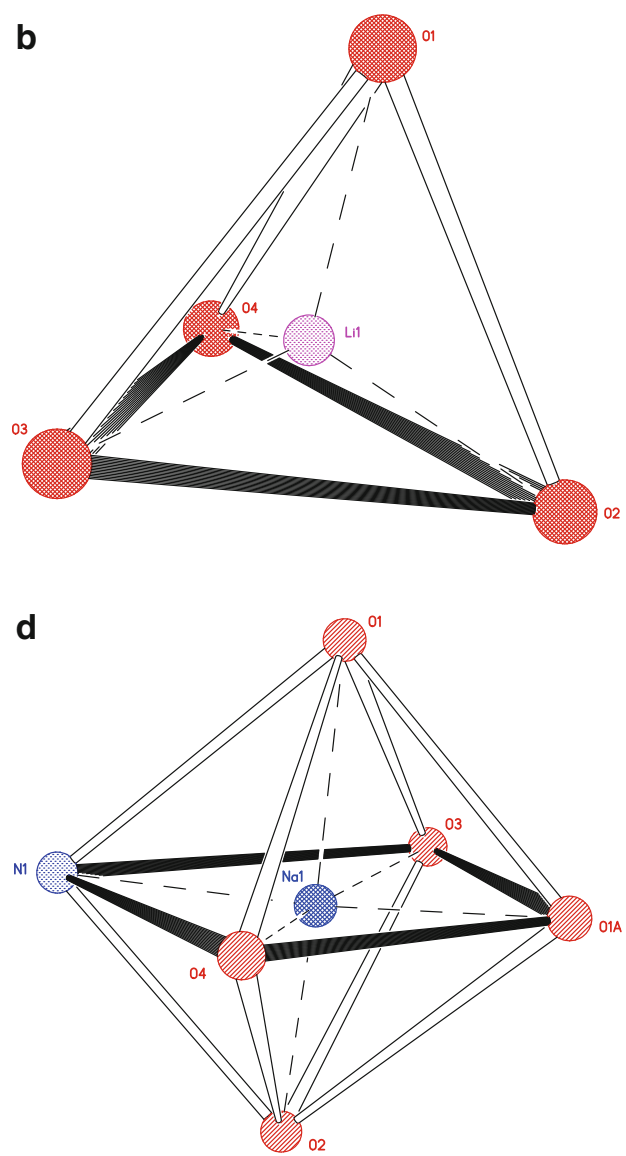

f

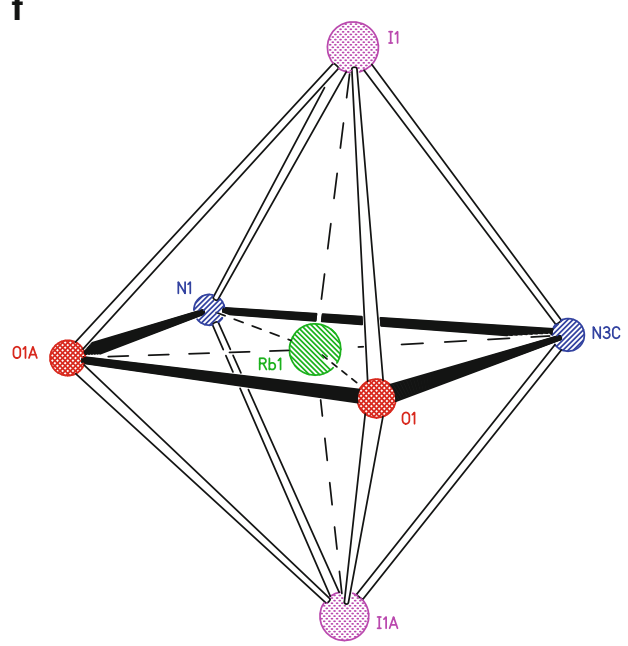

Fig. 8 The coordination polyhedra of the central atoms. The symmetry generated atoms indicated by dashed lines are obtained by symmetry transformations described in Fig. 1, 2, 3, 4, 5, and 6

three dimensional hydrogen-bonded network. In addition, the dinuclear compounds $\mathbf{2} \mathbf{b}$ and $\mathbf{2 c}$ are interlinked by intramolecular $\mathrm{O}-\mathrm{H} \cdots \mathrm{O}$ hydrogen bonds. In compounds $\mathbf{3 c}$ and $\mathbf{4 c}$ only $\mathrm{O}-\mathrm{H} \cdots \mathrm{N}$ intermolecular hydrogen bonds exist, and these ones link neighbouring hybrid nets to the three dimensional network. The analysis of the intermolecular short contacts (the shortest $\mathrm{C}-\mathrm{H} \cdots \mathrm{A}$ contact exists in compound 2c for $\mathrm{C} 4-\mathrm{H} 4 \mathrm{~B} \cdots \mathrm{O} 99$ atoms with $\mathrm{H} \cdots \mathrm{A}$ and C...A distances 2.58 and $3.54 \AA$, respectively) shows absence of the interaction which can be classified as weak hydrogen bonds [53, 54].

The characteristic very broad bands observed at a range of $3,448-3,482 \mathrm{~cm}^{-1}$ (Table 6) in all of the presented compounds originate from asymmetric $\mathrm{O}-\mathrm{H}$ vibrations of 
Table 4 The geometric properties of weighted least-squares internal polyhedra planes in studied compounds $\left(\AA,^{\circ}\right)$

\begin{tabular}{|c|c|c|c|c|}
\hline Plane A & Plane B & $\begin{array}{l}\text { Maximum deviating atom } \\
\text { within plane A }\end{array}$ & $\begin{array}{l}\text { Deviation of the metal } \\
\text { atom from plane A }\end{array}$ & $\begin{array}{l}\text { Dihedral angle between } \\
\text { planes A and B }\end{array}$ \\
\hline \multicolumn{5}{|l|}{$2 b$} \\
\hline $\mathrm{O} 1 / \mathrm{N} 1 / \mathrm{O} 2 / \mathrm{O} 4$ & $\mathrm{O} 1 / \mathrm{N} 1 / \mathrm{O} 3 / \mathrm{O} 1^{\mathrm{i}}$ & $0.0352(10)$ for $\mathrm{O} 1$ & $0.1417(12)$ & $85.95(3)$ \\
\hline $\mathrm{O} 1 / \mathrm{N} 1 / \mathrm{O} 3 / \mathrm{O} 1^{\mathrm{i}}$ & $\mathrm{O} 2 / \mathrm{O} 4 / \mathrm{O} 3 / \mathrm{O} 1^{\mathrm{i}}$ & $0.3319(11)$ for $\mathrm{N} 1$ & $0.0719(10)$ & $86.12(4)$ \\
\hline $\mathrm{O} 2 / \mathrm{O} 4 / \mathrm{O} 3 / \mathrm{O} 1^{\mathrm{i}}$ & $\mathrm{O} 1 / \mathrm{N} 1 / \mathrm{O} 2 / \mathrm{O} 4 /$ & $0.3604(11)$ for $\mathrm{O} 4$ & $0.0469(12)$ & $85.66(4)$ \\
\hline \multicolumn{5}{|l|}{$2 c$} \\
\hline 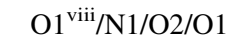 & $\mathrm{O} 1^{\mathrm{viii}} / \mathrm{N} 1 / \mathrm{O} 3 / \mathrm{O} 4$ & $0.2282(34)$ for $\mathrm{N} 1$ & $0.0483(34)$ & $84.33(14)$ \\
\hline $\mathrm{O} 1^{\mathrm{viii}} / \mathrm{N} 1 / \mathrm{O} 3 / \mathrm{O} 4$ & $\mathrm{O} 2 / \mathrm{O} 1 / \mathrm{O} 3 / \mathrm{O} 4$ & $0.0020(44)$ for $\mathrm{O} 1^{\text {viii }}$ & $0.1395(46)$ & $85.09(14)$ \\
\hline $\mathrm{O} 2 / \mathrm{O} 1 / \mathrm{O} 3 / \mathrm{O} 4$ & $\mathrm{O} 1^{\mathrm{viii}} / \mathrm{N} 1 / \mathrm{O} 2 / \mathrm{O} 1$ & $0.2512(40)$ for $\mathrm{O} 3$ & $0.0735(43)$ & $87.22(15)$ \\
\hline \multicolumn{5}{|l|}{$3 c$} \\
\hline $\mathrm{N} 1 / \mathrm{O} 1^{\mathrm{ii}} / \mathrm{I} 1 / \mathrm{I} 1^{\mathrm{iv}}$ & $\mathrm{N} 2^{\mathrm{iii}} / \mathrm{O} 1 / \mathrm{I} 1 / \mathrm{I} 1^{\mathrm{iv}}$ & $0.5141(02)$ for $\mathrm{N} 1$ & $0.1303(09)$ & $88.04(4)$ \\
\hline $\mathrm{N} 2^{\mathrm{iii}} / \mathrm{O} 1 / \mathrm{I} 1 / \mathrm{I} 1^{\mathrm{iv}}$ & $\mathrm{N} 2^{\mathrm{iii}} / \mathrm{O} 1 / \mathrm{N} 1 / \mathrm{O} 1^{\mathrm{ii}}$ & $0.2476(10)$ for $\mathrm{N} 2^{\mathrm{iii}}$ & $0.3038(12)$ & $90.00(1)$ \\
\hline $\mathrm{N} 2^{\mathrm{iii}} / \mathrm{O} 1 / \mathrm{N} 1 / \mathrm{O} 1^{\mathrm{ii}}$ & $\mathrm{N} 1 / \mathrm{O} 1^{\mathrm{ii}} / \mathrm{I} 1 / \mathrm{I} 1^{\mathrm{iv}}$ & $0.0000(0)$ & $0.0000(00)$ & $90.00(1)$ \\
\hline \multicolumn{5}{|l|}{$4 c$} \\
\hline $\mathrm{N} 1 / \mathrm{O} 1 / \mathrm{I} 1 / \mathrm{I} 1^{\mathrm{vii}}$ & $\mathrm{N} 3^{\mathrm{i}} / \mathrm{O} 1^{\mathrm{v}} / \mathrm{I} 1 / \mathrm{I} 1^{\mathrm{vii}}$ & $0.5840(17)$ for $\mathrm{N} 1$ & $0.1404(15)$ & $88.04(6)$ \\
\hline $\mathrm{N} 3^{\mathrm{i}} / \mathrm{O} 1^{\mathrm{v}} / \mathrm{I} 1 / \mathrm{I} 1^{\mathrm{vii}}$ & $\mathrm{N} 3^{\mathrm{i}} / \mathrm{O} 1^{\mathrm{v}} / \mathrm{N} 1 / \mathrm{O} 1$ & $0.2649(17)$ for $\mathrm{N} 3^{\mathrm{i}}$ & $0.4168(16)$ & $90.00(1)$ \\
\hline $\mathrm{N} 3^{\mathrm{i}} / \mathrm{O} 1^{\mathrm{v}} / \mathrm{N} 1 / \mathrm{O} 1$ & $\mathrm{~N} 1 / \mathrm{O} 1 / \mathrm{I} 1 / \mathrm{I} 1^{\mathrm{vii}}$ & $0.0000(0)$ & $0.0000(0)$ & $90.00(1)$ \\
\hline
\end{tabular}

Symmetry codes as in Table 2

Table 5 Bond valences (v.u.)

\begin{tabular}{|c|c|c|c|c|c|c|c|c|c|c|c|}
\hline \multicolumn{2}{|l|}{$1 a$} & \multicolumn{2}{|l|}{$1 \mathrm{c}$} & \multicolumn{2}{|l|}{$2 b$} & \multicolumn{2}{|l|}{$2 c$} & \multicolumn{2}{|l|}{$3 c$} & \multicolumn{2}{|l|}{$4 c$} \\
\hline Li1-O2 & 0.282 & Li1-O4 & 0.304 & $\mathrm{Na} 1-\mathrm{O} 4$ & 0.248 & $\mathrm{Na} 1-\mathrm{O} 2$ & 0.236 & $\mathrm{~K} 1-\mathrm{I} 1 / \mathrm{I} 1^{\mathrm{iv}}$ & 0.193 & $\mathrm{Rb} 1-\mathrm{I} 1 / \mathrm{I} 1^{\mathrm{iv}}$ & 0.208 \\
\hline Li1-O3 & 0.280 & Li1-O2 & 0.288 & $\mathrm{Na} 1-\mathrm{O} 3$ & 0.226 & $\mathrm{Na} 1-\mathrm{O} 3$ & 0.225 & $\mathrm{~K} 1-\mathrm{O} 1$ & 0.171 & $\mathrm{Rb} 1-\mathrm{O} 1$ & 0.150 \\
\hline Li1-O4 & 0.276 & Li1-O3 & 0.278 & $\mathrm{Na} 1-\mathrm{O} 2$ & 0.191 & $\mathrm{Na} 1-\mathrm{O} 4$ & 0.194 & $\mathrm{~K} 1-\mathrm{O} 1^{\mathrm{ii}}$ & 0.151 & $\mathrm{Rb} 1-\mathrm{O} 1^{\mathrm{v}}$ & 0.178 \\
\hline \multirow[t]{3}{*}{ Li1-O1 } & 0.273 & Li1-O1 & 0.266 & $\mathrm{Na} 1-\mathrm{O} 1$ & 0.183 & $\mathrm{Na} 1-\mathrm{O} 1^{\text {viii }}$ & 0.172 & $\mathrm{~K} 1-\mathrm{N} 1$ & 0.102 & $\mathrm{Rb} 1-\mathrm{N} 1$ & 0.109 \\
\hline & & & & $\mathrm{Na} 1-\mathrm{O} 1^{\mathrm{i}}$ & 0.143 & $\mathrm{Na} 1-\mathrm{O} 1$ & 0.149 & $\mathrm{~K} 1-\mathrm{N} 2$ & 0.059 & $\mathrm{Rb} 1-\mathrm{N} 3^{\mathrm{i}}$ & 0.073 \\
\hline & & & & Na1-N1 & 0.167 & Na1-N1 & 0.164 & & & & \\
\hline
\end{tabular}

Symmetry codes as in Table 2

water molecules. The $\mathrm{C}-\mathrm{N}$ stretching vibrations of the hmta molecules existing at $815 \mathrm{~cm}^{-1}$ for pure and outer coordination sphere (compounds 1a and 1c) hmta molecules are split into two bands (mostly lower shifted, Table 6) in compounds $\mathbf{2 b}, \mathbf{2 c}, \mathbf{3 c}$ and $\mathbf{4 c}$ due to formation of metal-N coordination bonds [55]. The two bands at 1,670 and $1,640 \mathrm{~cm}^{-1}$ (Table 6) existing in compounds $\mathbf{2 b}$ and $2 \mathrm{c}$ spectra proof that these compounds contain two types of water molecules located in outer and inner coordination sphere (Table 6) [56]. For other compounds (1a, $1 \mathbf{c}, 3 \mathbf{3 c}, \mathbf{4 c})$ only bands originating from the inner coordination sphere water molecules are observed (Table 6). The bands at about $700 \mathrm{~cm}^{-1}$ of $v_{\mathrm{M}-\mathrm{H} 2 \mathrm{O}}$ vibrations (Table 4) proof coordination of water molecules to the metal ions $[33,55,57]$. The band at about $1,240 \mathrm{~cm}^{-1}$ is not split in the studied compounds what proofs that in all cases at least one nitrogen atom is not coordinated to the metal ion [33]. In all analysed compounds the stretching vibrations of hmta methylene groups are distinctly shifted and slightly broadened in comparison to the pure ligand due to different surrounding of the $\mathrm{CH}_{2}$ groups in the crystal nets of the studied compounds and pure hmta [56, 58, 59].

The thermal decomposition of the studied compounds is a gradual process (Scheme 1). In all compounds the decomposition begins with endothermic removal of water molecules. In general, water molecules are lost in two steps apart from compounds $\mathbf{3 c}$ and $\mathbf{4 c}$ where they are removed in a single process. For each compound the water evolution starts at different temperatures. In $\mathbf{2 b}$ water evaporation starts at $23{ }^{\circ} \mathrm{C}$ whilst in $\mathbf{3 c}$ and $\mathbf{4 c}$ the process begins at 73 and $58{ }^{\circ} \mathrm{C}$, respectively. Next, the anhydrous coordination compounds lose hmta molecules. In $\mathbf{2 b}, \mathbf{2 c}, \mathbf{3 c}$, and $\mathbf{4 c}$ the whole amine is released during its one-step endothermic sublimation process. It is a quick process and after this, the sublimated hmta molecules are oxidised to volatile products-the ion current signals corresponding to $\mathrm{C}^{+}, \mathrm{CO}^{+}$, 
Table 6 Vibrational frequencies $\left(\mathrm{cm}^{-1}\right)$ and their assignment in studied compounds

\begin{tabular}{|c|c|c|c|c|c|c|c|}
\hline 1a & $1 c$ & $\mathbf{2 b}$ & $2 c$ & $3 c$ & $4 c$ & hmta $[65,66]$ & Assignment \\
\hline & $3481 b b$ & $3486 b b$ & $3480 \mathrm{bb}$ & $3482 \mathrm{bb}$ & & & $v_{\mathrm{as}}-(\mathrm{O}-\mathrm{H})$ \\
\hline $3452 w$ & & $3448 b b$ & $3453 b b$ & $3463 b b$ & & & $v_{\mathrm{as}}-(\mathrm{O}-\mathrm{H})$ \\
\hline $2964 w$ & & $2951 \mathrm{vw}$ & $2963 \mathrm{vw}$ & $2954 \mathrm{vw}$ & $2956 w$ & 2955 & $v_{\mathrm{s}}\left(\mathrm{CH}_{2}\right)$ \\
\hline \multirow[t]{3}{*}{$2937 w$} & 2936w & $2938 w$ & 2936w & & & 2949 & $v_{\mathrm{as}}\left(\mathrm{CH}_{2}\right)$ \\
\hline & & & & $2923 w$ & 2926w & 2934 & $v_{\mathrm{s}}(\mathrm{CH})$ \\
\hline & & & & $2905 \mathrm{vw}$ & & 2909 & $v_{\mathrm{s}}\left(\mathrm{CH}_{2}\right)$ \\
\hline \multirow[t]{2}{*}{ 2888w } & $2893 w$ & $2890 w$ & $2893 w$ & $2874 w$ & $2879 w$ & 2874 & $v_{\mathrm{s}}\left(\mathrm{CH}_{2}\right)$ \\
\hline & & $1669 \mathrm{~m}$ & $1669 w$ & & & & $\delta(\mathrm{O}-\mathrm{H})_{\text {outer coordination sphere water molecules }}$ \\
\hline \multirow[t]{2}{*}{$1617 \mathrm{vw}$} & & $1637 \mathrm{vw}$ & $1636 w$ & $1637 \mathrm{vw}$ & $1608 \mathrm{vw}$ & & $\delta(\mathrm{O}-\mathrm{H})_{\text {inner }}$ coordination sphere water molecules \\
\hline & $1487 \mathrm{vw}$ & $1488 \mathrm{vw}$ & $1481 \mathrm{vw}$ & $1482 w$ & $1483 w$ & 1485 & $\rho\left(\mathrm{CH}_{2}\right), \rho\left(\mathrm{CH}_{2}\right), \mathrm{CNC}$ deformation \\
\hline \multirow[t]{2}{*}{$1463 \mathrm{~m}$} & $1465 \mathrm{~m}$ & $1465 \mathrm{~s}$ & $1466 \mathrm{~s}$ & $1461 \mathrm{~s}$ & $1461 \mathrm{~s}$ & 1460 & $\sigma\left(\mathrm{CH}_{2}\right), \mathrm{CH}_{2}$ deformation \\
\hline & $1448 \mathrm{vw}$ & $1448 \mathrm{vw}$ & $1448 \mathrm{vw}$ & & & 1440 & $\sigma\left(\mathrm{CH}_{2}\right)$ \\
\hline \multirow[t]{2}{*}{$1381 \mathrm{~m}$} & $1381 \mathrm{~m}$ & $1379 s$ & $1380 \mathrm{~m}$ & $1379 \mathrm{~s}$ & $1383 \mathrm{~s}$ & 1370 & $\tau\left(\mathrm{CH}_{2}\right)$ \\
\hline & $1353 w$ & $1350 w$ & $1349 w$ & $1351 w$ & $1337 w$ & 1346 & $\omega\left(\mathrm{CH}_{2}\right)$ \\
\hline \multirow[t]{2}{*}{ 1320vw } & $1339 \mathrm{vw}$ & $1323 \mathrm{vw}$ & $1319 \mathrm{vw}$ & $1322 \mathrm{w}$ & & 1324 & $\tau\left(\mathrm{CH}_{2}\right)$ \\
\hline & & $1314 \mathrm{vw}$ & $1313 \mathrm{vw}$ & & & 1306 & $\omega\left(\mathrm{CH}_{2}\right), \tau\left(\mathrm{CH}_{2}\right)$ \\
\hline $1240 \mathrm{~s}$ & $1238 \mathrm{~s}$ & $1237 \mathrm{vs}$ & $1238 \mathrm{vs}$ & $1239 v s$ & $1241 \mathrm{vs}$ & 1240 & $\rho\left(\mathrm{CH}_{2}\right), v(\mathrm{C}-\mathrm{N})$ \\
\hline \multirow[t]{3}{*}{$1185 \mathrm{vw}$} & $1187 \mathrm{vw}$ & $1183 \mathrm{vw}$ & $1198 \mathrm{vw}$ & $1207 w$ & & 1192 & $\omega\left(\mathrm{CH}_{2}\right)$ \\
\hline & $1122 \mathrm{vw}$ & $1121 \mathrm{vw}$ & $1127 \mathrm{vw}$ & $1129 \mathrm{vw}$ & & 1129 & $\mathrm{CNC}$ deformation \\
\hline & $1053 w$ & $1058 w$ & $1052 w$ & $1047 w$ & & 1048 & $\tau\left(\mathrm{CH}_{2}\right), \mathrm{CNC}$ deformation, $\delta(\mathrm{NCN})$ \\
\hline \multirow[t]{2}{*}{$1007 \mathrm{vs}$} & $1008 \mathrm{vs}$ & $1008 \mathrm{vs}$ & $1008 \mathrm{vs}$ & $1007 \mathrm{vs}$ & $1008 \mathrm{vs}$ & 1007 & $v(\mathrm{C}-\mathrm{N})$ \\
\hline & $947 w$ & $937 w$ & $935 w$ & & & 933 & $\rho\left(\mathrm{CH}_{2}\right)$ \\
\hline $938 w$ & & & $920 \mathrm{vw}$ & $929 w$ & $929 w$ & 925 & $v(\mathrm{C}-\mathrm{N}), \rho\left(\mathrm{CH}_{2}\right)$ \\
\hline \multirow[t]{2}{*}{$815 \mathrm{~m}$} & $815 \mathrm{~m}$ & $817 \mathrm{~m}, 794 \mathrm{w}$ & $814 \mathrm{~m}, 797 \mathrm{w}$ & $812 \mathrm{~s}, 782 \mathrm{w}$ & $805 \mathrm{~m}, 784 \mathrm{~m}$ & 815 & $v(\mathrm{C}-\mathrm{N}), \rho\left(\mathrm{CH}_{2}\right)$ \\
\hline & & $783 w$ & & & & 779 & $v(\mathrm{C}-\mathrm{N})$ \\
\hline \multirow[t]{4}{*}{$688 \mathrm{~m}$} & $688 \mathrm{~m}$ & $738 \mathrm{~m}$ & $720 \mathrm{~m}$ & $681 \mathrm{~m}$ & $682 \mathrm{~m}$ & & $v(\mathrm{M}-\mathrm{O})$ \\
\hline & & $691 \mathrm{~s}$ & $668 \mathrm{~m}$ & $672 \mathrm{~s}$ & $670 \mathrm{~m}$ & 673 & $\delta(\mathrm{N}-\mathrm{C}-\mathrm{N}), \mathrm{CNC}$ deformation \\
\hline & $531 \mathrm{vw}$ & $512 \mathrm{vw}$ & & $512 \mathrm{vw}$ & $510 \mathrm{vw}$ & 512 & $\tau(\mathrm{NCN})$ \\
\hline & $462 \mathrm{vw}$ & & $458 \mathrm{vw}$ & & & 463 & $\delta(\mathrm{NCN})$ \\
\hline
\end{tabular}

$v w$ very weak, $w$ weak, $m$ medium strength, $s$ strong, $v s$ very strong, $v$ stretching, $\delta$ bending, $\rho$ rocking, $\sigma$ scissoring, $\tau$ waging, $\omega$ twisting, $s$ symmetric, as asymmetric, $b b$ broad band

$\mathrm{CO}_{2}{ }^{+}, \mathrm{N}^{+}, \mathrm{NO}^{+}$and $\mathrm{HCOOH}^{+}$are observed [60] in generated gases. The increase of ion currents is observed at higher temperatures comparing to the temperature of the amine sublimation due to crystallization of the sublimated hmta molecules inside the mass spectrometer system [61]. In $1 \mathbf{a}$ and $1 \mathbf{c}$ the amine molecules are removed in two substages. First, similarly to above described compounds, the hmta molecules sublimates. In the second substage, the remaining amine molecules are combusted within the sample in an exothermic process [62]. At this point the decomposition of the investigated compounds decelerates and the alkali metal halides are formed. Next the salts begin to decompose, at first this is a slow process with almost negligible mass loss-the exception is compound 1c where significant mass loss is seen earlier, at lower temperatures (lithium iodide melts at about $460{ }^{\circ} \mathrm{C}$ ). The further thermal decomposition accelerates when the temperature reaches the melting point of the formed halides. In case of $\mathbf{1 a}, \mathbf{1 c}, \mathbf{2 c}$, and $\mathbf{3 c}$ the salts are totally removed. In $\mathbf{2 b}$ and $\mathbf{4 c}$ the salts undergo partially evaporation and partially decomposition to the alkali metal oxides and the final, stable products are $\mathrm{Na}_{2} \mathrm{O}$ and $\mathrm{Rb}_{2} \mathrm{O}$ (respectively, for $\mathbf{2 b}$ and $\mathbf{4 c}$ ).

\section{Conclusion}

The reaction of alkali metal halogenides with hmta (performed in molar ratio 1:1) leads to the formation of coordination complex compounds, mononuclear in case of lithium compounds, dinuclear sodium compounds and polymeric potassium and rubidium compounds, thus the ability to formation of multinuclear species depends only on the type of metal and it increases with increasing atomic 
Scheme 1 Stages of the thermal decomposition of studied compounds (m.l. experimental mass loss/ theoretical mass loss, v.p. volatile products, *product was confirmed by XRPD) 1a)

$\left[\mathrm{Li}\left(\mathrm{H}_{2} \mathrm{O}\right)_{4}\right]^{+} \cdot \mathrm{C}_{6} \mathrm{H}_{12} \mathrm{~N}_{4} \cdot \mathrm{Cl}^{-}$

stage I, v.p.: $\mathrm{H}_{2} \mathrm{O}^{+}, \mathrm{H}^{+}, \mathrm{HO}^{+}$; m.l. $14.38 \% / 14.14 \%\left(38-141^{\circ} \mathrm{C}\right) 87^{\circ} \mathrm{C}$ endo

$\downarrow-2 \mathrm{H}_{2} \mathrm{O}$

$\left[\mathrm{Li}\left(\mathrm{H}_{2} \mathrm{O}\right)_{2}\right]^{+} \cdot \mathrm{C}_{6} \mathrm{H}_{12} \mathrm{~N}_{4} \cdot \mathrm{Cl}^{-}$

stage II, v.p.: $\mathrm{H}_{2} \mathrm{O}^{+}, \mathrm{H}^{+}, \mathrm{HO}^{+}$; m.l. $17.55 \% / 14.14 \%\left(141-175^{\circ} \mathrm{C}\right) 155^{\circ} \mathrm{C}$ endo

$\downarrow-2 \mathrm{H}_{2} \mathrm{O}$

$\mathrm{LiCl} \cdot \mathrm{C}_{6} \mathrm{H}_{12} \mathrm{~N}_{4}$

stage III, m.1. $51.54 \% / 55.05 \%$

stage IIIa v.p.: $\mathrm{C}_{6} \mathrm{H}_{12} \mathrm{~N}_{4}^{+} ;$m.1. $47.45 \% /-;\left(175-267^{\circ} \mathrm{C}\right) 236^{\circ} \mathrm{C}$ endo

stage IIIb v.p.: $\mathrm{C}_{6} \mathrm{H}_{12} \mathrm{~N}_{4}^{+}, \mathrm{CH}_{2}{ }^{+}$or $\mathrm{N}^{+}, \mathrm{CH}^{+}, \mathrm{CO}^{+}, \mathrm{CO}_{2}{ }^{+}, \mathrm{NO}^{+}, \mathrm{NO}_{2}{ }^{+}$; m.l. $4.09 \% /-;\left(267-499^{\circ} \mathrm{C}\right) 472^{\circ} \mathrm{C}$ exo

$\downarrow$ - hmta

$\mathrm{LiCl}$

stage IV v.p.: $\mathrm{Cl}^{+}$,; m.1. $18.18 \% / 16.65 \% ;\left(499-912^{\circ} \mathrm{C}\right) 636^{\circ} \mathrm{C}$ endo

$\downarrow-\mathrm{LiCl}$

Total decomposition

1c)

$\left[\mathrm{Li}\left(\mathrm{H}_{2} \mathrm{O}\right)_{4}\right]^{+} \cdot \mathrm{C}_{6} \mathrm{H}_{12} \mathrm{~N}_{4} \cdot \mathrm{I}^{-}$

stage I v.p.: $\mathrm{H}_{2} \mathrm{O}^{+}, \mathrm{H}^{+}, \mathrm{HO}^{+}$; m.l. $10.85 \% / 10.40 \%\left(32-127^{\circ} \mathrm{C}\right) 96^{\circ} \mathrm{C}$ endo

$\downarrow-2 \mathrm{H}_{2} \mathrm{O}$

$\left[\mathrm{Li}\left(\mathrm{H}_{2} \mathrm{O}\right)_{2}\right]^{+} \cdot \mathrm{C}_{6} \mathrm{H}_{12} \mathrm{~N}_{4} \cdot \mathrm{I}$

stage II v.p.: $\mathrm{H}_{2} \mathrm{O}^{+}, \mathrm{H}^{+}, \mathrm{HO}^{+} ;$m.l. $18.07 \% / 18.10 \%\left(127-196^{\circ} \mathrm{C}\right) 163^{\circ} \mathrm{C}$ endo

$\downarrow-2 \mathrm{H}_{2} \mathrm{O}$

$\mathrm{LiI} \cdot \mathrm{C}_{6} \mathrm{H}_{12} \mathrm{~N}_{4}$

stage III, m.l. $71.45 \% / 71.49 \%$

stage IIIa v.p.: $\mathrm{C}_{6} \mathrm{H}_{12} \mathrm{~N}_{4}^{+}, \mathrm{CH}_{2}{ }^{+}$or $\mathrm{N}^{+}, \mathrm{CH}^{+}, \mathrm{CO}^{+}, \mathrm{CO}_{2}{ }^{+}, \mathrm{NO}^{+}, \mathrm{NO}_{2}^{+}$; m.l. $18.39 \% /$; $\left(196-260^{\circ} \mathrm{C}\right) 234^{\circ} \mathrm{C}$ exo

stage IIIb v.p.: $\mathrm{C}_{6} \mathrm{H}_{12} \mathrm{~N}_{4}^{+}, \mathrm{CH}_{2}^{+}$or $\mathrm{N}^{+}, \mathrm{CH}^{+}, \mathrm{CO}^{+}, \mathrm{CO}_{2}^{+}, \mathrm{NO}^{+}, \mathrm{NO}_{2}^{+}, \mathrm{I}^{+}$

$\downarrow-\mathrm{C}_{6} \mathrm{H}_{12} \mathrm{~N}_{4},-\mathrm{LiI}$

m.1. $53.06 \% /-;\left(260-897^{\circ} \mathrm{C}\right) 472^{\circ} \mathrm{C}$ exo

decomposition

2b)

$\left[\mathrm{Na}\left(\mathrm{H}_{2} \mathrm{O}\right)_{4}\left(\mathrm{C}_{6} \mathrm{H}_{12} \mathrm{~N}_{4}\right)\right]_{2}{ }^{2+} \cdot 2 \mathrm{H}_{2} \mathrm{O} \cdot 2 \mathrm{Br}$

stage I, v.p.: $\mathrm{H}_{2} \mathrm{O}^{+}, \mathrm{H}^{+}, \mathrm{HO}^{+}$; m.l. $11.23 \% / 13.50 \%$; $\left(23-99^{\circ} \mathrm{C}\right) 81^{\circ} \mathrm{C}$ endo

$\downarrow-5 \mathrm{H}_{2} \mathrm{O}$

$\left[\mathrm{Na}\left(\mathrm{H}_{2} \mathrm{O}\right)_{2.5}\left(\mathrm{C}_{6} \mathrm{H}_{12} \mathrm{~N}_{4}\right)\right]_{2}{ }^{2+} \cdot 2 \mathrm{Br}^{-}$

stage II, v.p.: $\mathrm{H}_{2} \mathrm{O}^{+}, \mathrm{H}^{+}, \mathrm{HO}^{+} ;$m.l. $11.04 \% / 13.50 \%\left(99-141^{\circ} \mathrm{C}\right) 125^{\circ} \mathrm{C}$ endo

$\downarrow-5 \mathrm{H}_{2} \mathrm{O}$

$\left[\mathrm{Na}\left(\mathrm{C}_{6} \mathrm{H}_{12} \mathrm{~N}_{4}\right)\right]_{2}^{2+} \cdot 2 \mathrm{Br}$

stage III v.p.: $\mathrm{C}_{6} \mathrm{H}_{12} \mathrm{~N}_{4}^{+}, \mathrm{CH}_{2}^{+}$or $\mathrm{N}^{+}, \mathrm{CH}^{+}, \mathrm{CO}^{+}, \mathrm{CO}_{2}^{+}, \mathrm{NO}^{+}, \mathrm{NO}_{2}^{+}$;

$\downarrow-2 \mathrm{C}_{6} \mathrm{H}_{12} \mathrm{~N}_{4}$

m.1. $42.18 \% / 42.08 \%\left(141-233^{\circ} \mathrm{C}\right) 214^{\circ} \mathrm{C}$ endo

$2 \mathrm{NaBr}$

| stage IV v.p.: $\mathrm{Br}^{+}$; m.1. $30.64 \% / 29.08 \%\left(298-874^{\circ} \mathrm{C}\right) 741^{\circ} \mathrm{C}$ endo, $828^{\circ} \mathrm{C}$ exo

$\downarrow-1.94 \mathrm{NaBr},-0.03 \mathrm{Br}_{2}, 0.02 \mathrm{O}_{2}$

$0.03 \mathrm{Na}_{2} \mathrm{O}$

2c)

$\left[\mathrm{Na}\left(\mathrm{H}_{2} \mathrm{O}\right)_{4}\left(\mathrm{C}_{6} \mathrm{H}_{12} \mathrm{~N}_{4}\right)\right]_{2}{ }^{2+} \cdot 2 \mathrm{H}_{2} \mathrm{O} \cdot 2 \mathrm{I}$

stage I: v.p.: $\mathrm{H}_{2} \mathrm{O}^{+}, \mathrm{H}^{+}, \mathrm{HO}^{+}$; m.l. $5.75 \% / 4.73 \%\left(36-72^{\circ} \mathrm{C}\right) 68^{\circ} \mathrm{C}$ endo

$\downarrow-2 \mathrm{H}_{2} \mathrm{O}$

$\left[\mathrm{Na}\left(\mathrm{H}_{2} \mathrm{O}\right)_{4}\left(\mathrm{C}_{6} \mathrm{H}_{12} \mathrm{~N}_{4}\right)\right]_{2}{ }^{2+} \cdot 2 \mathrm{I}^{-}$

stage II, v.p.: $\mathrm{H}_{2} \mathrm{O}^{+}, \mathrm{H}^{+}, \mathrm{HO}^{+}$; m.l. $18.60 \% / 18.94 \%\left(72-142^{\circ} \mathrm{C}\right), 108^{\circ} \mathrm{C}$ endo

$\downarrow-8 \mathrm{H}_{2} \mathrm{O}$

$\left[\mathrm{Na}\left(\mathrm{C}_{6} \mathrm{H}_{12} \mathrm{~N}_{4}\right)\right]_{2}^{2+} \cdot 2 \mathrm{I}$

stage III, m.l. $77.18 \% / 77.82 \%$

stage IIIa v.p.: $\mathrm{C}_{6} \mathrm{H}_{12} \mathrm{~N}_{4}{ }^{+}, \mathrm{I}^{+}$; m.l. $41.79 \% / — ;\left(142-238^{\circ} \mathrm{C}\right) 206^{\circ} \mathrm{C}$ endo, $230^{\circ} \mathrm{C}$ endo

stage IIIb v.p.: $\mathrm{I}^{+} ;$m.1. $35.39 \% /$-; $\left(238-786^{\circ} \mathrm{C}\right) 652^{\circ} \mathrm{C}$ endo

$\downarrow-2 \mathrm{C}_{6} \mathrm{H}_{12} \mathrm{~N}_{4},-\mathrm{NaI}$

Total decomposition

$3 \mathrm{c})$

$\left[\mathrm{K}\left(\mathrm{H}_{2} \mathrm{O}\right)\left(\mathrm{C}_{6} \mathrm{H}_{12} \mathrm{~N}_{4}\right) \mathrm{I}\right]$

stage I, v.p.: $\mathrm{H}_{2} \mathrm{O}^{+}, \mathrm{H}^{+}, \mathrm{HO}^{+} ;$m.1. $4.85 \% / 5.55 \%\left(73-116^{\circ} \mathrm{C}\right) 87^{\circ} \mathrm{C}$ endo

$\downarrow-\mathrm{H}_{2} \mathrm{O}$

$\left[\mathrm{K}\left(\mathrm{C}_{6} \mathrm{H}_{12} \mathrm{~N}_{4}\right) \mathrm{I}\right]$

stage II v.p.: $\mathrm{C}_{6} \mathrm{H}_{12} \mathrm{~N}_{4}^{+}, \mathrm{CH}_{2}{ }^{+}$or $\mathrm{N}^{+}, \mathrm{CH}^{+}, \mathrm{CO}^{+}, \mathrm{CO}_{2}{ }^{+}, \mathrm{NO}^{+}, \mathrm{NO}_{2}{ }^{+}$;

$\downarrow-\mathrm{C}_{6} \mathrm{H}_{12} \mathrm{~N}_{4}$

m.1. $45.06 \% / 43.24 \%\left(116-232^{\circ} \mathrm{C}\right) 223^{\circ} \mathrm{C}$ endo

stage III v.p.; $I^{+}$; m.1. $49.25 \%-51.2 \%\left(530-852^{\circ} \mathrm{C}\right) 767^{\circ} \mathrm{C}$ endo

$\downarrow-\mathrm{KI}$

Total decomposition

$4 c)$

$\left[\mathrm{Rb}\left(\mathrm{H}_{2} \mathrm{O}\right)\left(\mathrm{C}_{6} \mathrm{H}_{12} \mathrm{~N}_{4}\right) \mathrm{I}\right]$

stage I, v.p.: $\mathrm{H}_{2} \mathrm{O}^{+}, \mathrm{H}^{+}, \mathrm{HO}^{+}$; m.l. $4.09 \% / 4.86 \%\left(58-108^{\circ} \mathrm{C}\right) 68^{\circ} \mathrm{C}$ endo

$\downarrow-\mathrm{H}_{2} \mathrm{O}$

$\left[\mathrm{Rb}\left(\mathrm{C}_{6} \mathrm{H}_{12} \mathrm{~N}_{4}\right) \mathrm{I}\right]$

stage II v.p.: $\mathrm{C}_{6} \mathrm{H}_{12} \mathrm{~N}_{4}^{+}, \mathrm{CH}_{2}^{+}$or $\mathrm{N}^{+}, \mathrm{CH}^{+}, \mathrm{CO}^{+}, \mathrm{CO}_{2}^{+}, \mathrm{NO}^{+}, \mathrm{NO}_{2}^{+}$;

$\downarrow-\mathrm{C}_{6} \mathrm{H}_{12} \mathrm{~N}_{4}$

$\mathrm{RbI}^{*}$ m.1. $36.45 \% / 37.83 \%\left(108-233^{\circ} \mathrm{C}\right) 222^{\circ} \mathrm{C}$ endo

stage III, m. $1.50 .81 \% / 50.25 \%\left(300-810^{\circ} \mathrm{C}\right) 645^{\circ} \mathrm{C}$ endo, $770^{\circ} \mathrm{C}$ exo

$\downarrow-0.66 \mathrm{RbI},-0.17 \mathrm{I}_{2},+0.09 \mathrm{O}_{2}$

$0.17 \mathrm{Rb}_{2} \mathrm{O}^{*}$ 


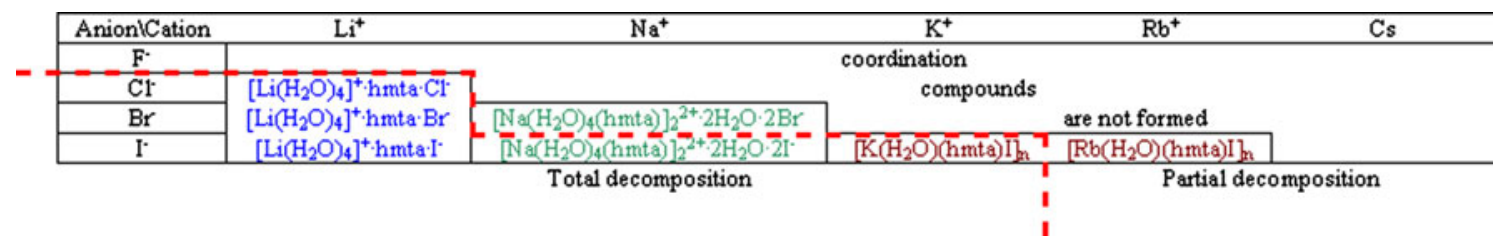

Fig. 9 The reactivity of hmta towards alkali metal halogenides, together with demarcation of differences in thermal decomposition

number (Fig. 9). In lithium compounds the hmta molecules are located in the outer coordination sphere and in sodium, potassium and rubidium compounds in the inner coordination sphere. The thermal decomposition of studied compounds proceeds via halogenides or metal oxides with evolving halogens [62-64] (Fig. 9).

\section{Supplementary data}

Tables of crystal data and structure refinement, anisotropic displacement coefficients, atomic coordinates and equivalent isotropic displacement parameters for non-hydrogen atoms, $\mathrm{H}$-atom coordinates and isotropic displacement parameters, bond lengths and interbond angles have been deposited with the Cambridge Crystallographic Data Centre under No CCDC859820, CCDC859821, CCDC859822, CCDC859823, CCDC859824, and CCDC859825, respectively for compounds $1 \mathbf{a}, \mathbf{1 c}, \mathbf{2 b}, \mathbf{2 c}, \mathbf{3 c}$, and $\mathbf{4 c}$.

Acknowledgment This study was financed by funds allocated by the Ministry of Science and Higher Education to the Institute of General and Ecological Chemistry, Technical University of Lodz.

Open Access This article is distributed under the terms of the Creative Commons Attribution License which permits any use, distribution, and reproduction in any medium, provided the original author(s) and the source are credited.

\section{References}

1. Silva JJRFD, Williams RJP (1991) The biological chemistry of the elements. Clarendon Press, Oxford

2. Hughes MN (1972) The inorganic chemistryof biological processes, 2nd edn. Wiley, New York

3. Hanzlik RP (1976) Inorganic aspects of biological and organic chemistry. Academic Press, New York

4. Pressman BC (1973) In: Eichhorn GL (ed) Inorganic chemistry. Elsevier, Amsterdam

5. Smith RM, Martell AE, Chen Y (1991) Pure Appl Chem 63:1015

6. Black CB, Huang HW, Covan JA (1994) Coord Chem Rev 135:165

7. Bryan JC, Kavallieratos K, Sachleben RA (2000) Inorg Chem 39:1568

8. Poonia NS, Bajaj AV (1979) Chem Rev 79:389

9. Olsher U, Izatt RM, Bradshaw JS, Dalley NK (1991) Chem Rev 91:137
10. Chattopadhyay T, Banu KS, Chattopadhyay S, Banerjee A, Mondal S, Suresh E, Das D (2009) Inorg Chem Comm 12:26

11. Fromm KM, Gueneau ED (2004) Polyhedron 23:1479

12. Fromm KM (2008) Coord Chem Rev 252:856

13. Steed JW (2001) Coord Chem Rev 215:171

14. Cram DJ, Cram JM (1974) Science 183:4127

15. Venkatasubramanian K, Joshi K, Poonia NS, Montfort WR, Ernst SR, Hackert ML (1985) J Inclusion Phenom 3:453

16. Poonia NS (1974) J Am Chem Soc 96:1974

17. Momany C, Clinger K, Hackert ML, Poonia NS (1986) J Inclusion Phenom 4:61

18. Poonia NS, Izatt RM, Christensen JJ (eds) (1979) Progress in macrocyclic chemistry, vol 1. Wiley, New York, p 115

19. Crichton RR (2008) Biological inorganic chemistry-an introduction. Elsevier, Belgium

20. Da Silva JJRF, Williams RJP (2001) The biological chemistry of the elements, the inorganic chemistry of life. Oxford, University Press, p 231

21. Haas KL, Franz KJ (2009) Chem Rev 109:4921

22. Phipps DA, Berton D (ed) (1995) Handbook of metal ligandinteraction in biological fluids. Part 2, Bioinorganic Medicine

23. Daniele PG, Foti C, Gianguzza A, Prenesti E, Sammartano S (2008) Coord Chem Rev 252:1093

24. Xu RB, Xu XY, Li SA, Wang MY, Yang XJ, Wang DQ, Huang YP, Xu CM (2010) Struct Chem 21:1085

25. He R, Liang Q, Song HH, Wei Z (2010) Struct Chem 21:923

26. Zhan CH, Feng YL (2010) Struct Chem 21:893

27. Wang Y, Şerb M, Englert U (2010) Struct Chem 21:203

28. Kaczmarek MT, Kubicki M, Radecka-Paryzek W (2010) Struct Chem 21:779

29. Liu FC, Zeng YF, Li JR, Bu XH, Zhang HJ, Ribas J (2005) Inorg Chem 44:7298

30. Bai Y, Shang WL, Dng DB, Sun JD, Gao H (2009) Spectrochimica Acta part A 72:407

31. Wang J, Djukic B, Cao JY, Alebrola A, Razavi FS, Pilkington M (2007) Inorg Chem 46:8650

32. Dohyun M, Sangmi K, Jaejoon P, Myoung SL (2006) J Am Chem Soc 128:3530

33. Agwara MO, Yufanyi MD, Foba-Tendo JN, Atamba MA, Tantoh Ndinteh D (2011) J Chem Pharm Res 3:196

34. Li BL, Song LX, Ding JG, Bian GQ, Yu KB, You XZ (1998) Chin J Struct Chem 17:209

35. Ganesh V, Seshasayee M, Aravamudan G, Heienrik D, Schenk H (1990) Acta Crystallogr Sect C 46:949

36. Carlucci L, Ciani G, Proserpio DM, Sironi A (1995) J Am Chem Soc 117:861

37. Ermer O, Eling A (1994) J Chem Soc Perkin Trans 2:925

38. Michelet A, Viossat B, Khodadad P, Rodier N (1981) Acta Crystallogr Sect B 37:2171

39. Pickardt J, Gong G (1995) Z Kristallogr 210:717

40. X-RED Version 118 STOE \& Cie GmbH Darmstadt Germany (1999)

41. Sheldrick GM (2008) Acta Crystallogr Sect A 64:112

42. Data processing module Copyright (C) 1994-1998 SETARAMFrance, Version 14 
43. Powder diffraction file international center of diffraction data (2003) 12 Campus Boulevard, Newton Square

44. Czubacka E, Kruszynski R, Sieranski T (2011) Struct Chem. doi: 10.1007/s11224-011-9888-7

45. Zachariasen WH (1978) J Less Common Metals 62:1

46. Brown ID (1997) Acta Cryst Sect B 53:381

47. Brown ID (1992) Acta Cryst Sect B 48:553

48. Trzesowska A, Kruszynski R, Bartczak TJ (2004) Acta Crystallogr Sect B 60:174

49. Trzesowska A, Kruszynski R, Bartczak TJ (2005) Acta Crystallogr Sect B 61:429

50. Trzesowska A, Kruszynski R, Bartczak TJ (2006) Acta Crystallogr Sect B 62:745

51. O'Keeffe M, Brese NE (1997) Acta Cryst Sect B 47:192

52. Taylor R, Kennard O (1982) J Am Chem Soc 104:5063

53. Desiraju GR, Steiner T (1999) The weak hydrogen bond in structural chemistry and biology. Oxford University Press, Oxford

54. Kruszynski R. (2011) Scientific bulletin of the technical University of Lodz 1086:5, Series Chemistry 50:5
55. Ndifon PT, Agwara MO, Paboudam AG, Yufanyi DM, Ngoune J, Galindo A, Álvarez E, Mohamadou A (2009) Trans Met Chem 34:745

56. Balicheva TG, Pologikh IV (1975) Russ J Inorg Chem 20:1769

57. Agwara MO, Ndifon PT, Ndikontar MK, Atamba MA (2008) Res J Chem Environ 12:87

58. Zhang Y, Li J, Nishiura M, Imamoto T (2000) J Mol Struct 523:257

59. Balicheva TG, Pologikh IV, Kovachev DI, Statelova AJ (1975) Russ J Inorg Chem 20:87

60. Sieranski T, Kruszynski R (2011) J Therm Anal Calorim. doi: 10.1007/s10973-011-1693-4

61. Trzesowska A, Kruszynski R (2008) J Coord Chem 61:2167

62. Kruszynski R (2011) Inorg Chim Acta 371:111

63. Kruszynski R (2010) Struct Chem 21:87

64. Rehman S, Arshad M, Khan SA, Masud K, Arshad N, Qureshi AH, Ghauri SA (2000) Thermochimica Acta 345:81

65. Bernstein MP, Sandford SA, Allamandola LJ, Chang S (1994) J Phys Chem 98:12206

66. Jensen JO (2002) Spectrochimica Acta Part A 58:1347 